\title{
Reconstruction of Marine Commercial Landings for the Brazilian Industrial and Artisanal Fisheries From 1950 to 2015
}

Kátia Meirelles Felizola Freire ${ }^{1 *}$, Zafira da Silva de Almeida ${ }^{2}$, José Raimundo Emanoel Trindade Amador ${ }^{3}$, José Augusto Aragão, Ana Rosa da Rocha Araújo ${ }^{5}$, Antônio Olinto Ávila-da-Silva ${ }^{6}$, Bianca Bentes 7 , Marcus Henrique Carneiro ${ }^{8}$, Julien Chiquieri ${ }^{9}$, Cezar Augusto Freire Fernandes ${ }^{10}$,

OPEN ACCESS

Edited by:

Cornelia E. Nauen

Mundus Maris, Belgium

Reviewed by:

Gabriel Vianna

University of Western Australia,

Australia

Alfonso Aguilar-Perera,

Universidad Autónoma de Yucatán,

Mexico

${ }^{*}$ Correspondence: Kátia Meirelles Felizola Freire kmffreire2018@gmail.com

Specialty section:

This article was submitted to Marine Fisheries, Aquaculture and Living Resources,

a section of the journal

Frontiers in Marine Science

Received: 27 January 2021 Accepted: 25 June 2021

Published: 27 July 2021

Citation:

Freire KMF, Almeida ZS, Amador JRET, Aragão JA, Araújo ARR, Ávila-da-Silva AO, Bentes $B$, Carneiro MH, Chiquieri J,

Fernandes $C A F$, Figueiredo $M B$,

Hostim-Silva M, Jimenez ÉA,

Keunecke KA, Lopes PFM, Mendonça JT, Musiello-Fernandes J, Olavo G, Primitivo C, Rotundo MM, Santana RF, Sant'Ana R, Scheidt G,

Silva LMA, Trindade-Santos I,

Velasco G and Vianna M (2021)

Reconstruction of Marine Commercial Landings for the Brazilian Industrial and Artisanal Fisheries From 1950 to 2015. Front. Mar. Sci. 8:659110.

doi: 10.3389/fmars.2021.659110
Marina Bezerra Figueiredo ${ }^{2}$, Maurício Hostim-Silva ${ }^{9}$, Érica Antunes Jimenez ${ }^{11}$, Karina Annes Keunecke ${ }^{12}$, Priscila Fabiana Macedo Lopes ${ }^{13}$, Jocemar Tomasino Mendonça ${ }^{14}$, Joelson Musiello-Fernandes ${ }^{9}$, George Olavo ${ }^{15}$, Camila Primitivo ${ }^{16}$, Matheus Marcos Rotundo ${ }^{17}$, Raynara Filho Santana', Rodrigo Sant'Ana ${ }^{18}$, Guilherme Scheidt ${ }^{19}$, Luis Maurício Abdon da Silva ${ }^{20}$, Isaac Trindade-Santos ${ }^{1}$, Gonzalo Velasco ${ }^{21}$ and Marcelo Vianna ${ }^{22}$

${ }^{1}$ Laboratório de Ecologia Pesqueira, Departamento de Engenharia de Pesca e Aquicultura, Universidade Federal de Sergipe, São Cristóvão, Brazil, ${ }^{2}$ Laboratório de Biologia Pesqueira, Departamento de Biologia, Universidade Estadual do Maranhão, São Luís, Brazil, ${ }^{3}$ Coordenadoria de Desenvolvimento da Pesca e Aquicultura, Agência de Pesca do Amapá, Macapá, Brazil, ${ }^{4}$ Consultant, Fortaleza, Brazil, ${ }^{5}$ Laboratório de Gestão e Extensão Pesqueira, Departamento de Engenharia de Pesca e Aquicultura (DEPAQ), Universidade Federal de Sergipe (UFS), São Cristóvão, Brazil, ${ }^{6}$ Unidade Laboratorial de Referência em Controle Estatístico da Produção Pesqueira Marinha (IP-ULRCEPPM), Instituto de Pesca, Santos, Brazil, ${ }^{7}$ Núcleo de Ecologia Aquática e Pesca, Universidade Federal do Pará (UFPA), Belém, Brazil, ${ }^{8}$ Núcleo Regional de Pesquisa do Litoral Norte (IP-NRPLN), Instituto de Pesca, Ubatuba, Brazil, ${ }^{9}$ Laboratório de Pesca e Aquicultura (LabPesca), Departamento de Ciências Agrárias e Biológicas (DCAB), Centro Universitário Norte do Espírito Santo (CEUNES), Universidade Federal do Espirito Santo (UFES), São Mateus, Brazil, ${ }^{10}$ Departamento de Ciências do Mar, Universidade Federal do Piauí (UFPl), Parnaíba, Brazil, " 11 Diretoria de Desenvolvimento da Pesca e Aquicultura (DDPA), Instituto de Extensão, Assistência e Desenvolvimento Rural do Amapá (RURAP), Macapá, Brazil, ${ }^{12}$ Instituto de Biologia, Universidade Federal Rural do Rio de Janeiro (UFRRJ), Rio de Janeiro, Brazil, ${ }^{13}$ Departamento de Ecologia, Universidade Federal do Rio Grande do Norte, Natal, Brazil, ${ }^{14}$ Núcleo Regional de Pesquisa do Litoral Sul (IP-NRPLS), Instituto de Pesca, Cananéia, Brazil, ${ }^{15}$ Laboratório de Biologia Pesqueira, Departamento de Ciências Biológicas, Universidade Estadual de Feira de Santana (UEFS), Feira de Santana, Brazil, ${ }^{16}$ Programa de Pós-graduação em Ecologia e Conservação da Biodiversidade, Universidade Estadual de Santa Cruz (UESC), Ilhéus, Brazil, ${ }^{17}$ Acervo Zoológico da Universidade de Santa Cecília (AZUSC), Santos, Brazil, ${ }^{18}$ Laboratório de Estudos Marinhos Aplicados, Escola do Mar, Ciência e Tecnologia (EMCT), Universidade do Vale do Itajaí (UNIVALI), Itajai, Brazil, ${ }^{19}$ Instituto de Ciências do Mar, Universidade Federal do Ceará (UFC), Fortaleza, Brazil, ${ }^{20}$ Núcleo de Pesquisas Aquáticas (NUPAq), Instituto de Pesquisas Científicas e Tecnológicas do Estado do Amapá (IEPA), Macapá, Brazil, ${ }^{21}$ Instituto de Oceanografia, Universidade Federal do Rio Grande (FURG), Rio Grande, Brazil, ${ }^{22}$ Instituto de Biologia, Universidade Federal do Rio de Janeiro (UFRJ), Rio de Janeiro, Brazil

Landing data are the most basic information used to manage fisheries, although they are often unavailable or incomplete. The objective of this work was to reconstruct the national database of marine commercial landings for the Brazilian industrial and artisanal fisheries, from 1950 to 2015. Total landings increased strongly from 1950 to mid-1980s and suffered sharp decline in the early 1990s, mainly associated to the collapse of sardine fisheries. After that, another period of increasing landings was observed, but at a much lower rate. Industrial landings always surpassed artisanal landings in Brazilian waters, except for the beginning of the time series, when many industrial fleets had not started yet, and in the early 2000s, when a change in the methodology for collecting landing statistics was implemented in the state of Pará 
leading to an overestimation of artisanal landings. Artisanal fisheries have been declining since 2005, which is worrisome due to the social impact it may have on local income and food security. Regional differences were also observed, with industrial landings being always higher than artisanal landings in southeastern-southern Brazil, while the opposite was true for the northern-northeastern regions. Higher landings were observed in the southeastern-southern regions when both artisanal and industrial fleets were combined. Sardine and demersal fishes were the main resources landed by industrial fishers. Artisanal fishers caught more species than their industrial counterpart, featuring Xiphopenaeus kroyeri, Cynoscion acoupa, and Ucides cordatus. Although the fishing of Epinephelus itajara was banned in Brazil, it continues to be landed. Yet, catches of this species and others under some threat status are still not properly registered, including: Carcharhinus longimanus, Galeorhinus galeus, Sphyrna lewini, Sphyrna mokarran, Pristis pectinata, and Pseudobatos horkelii. Fishing resources not identified in previous landing reconstruction efforts, such as sea urchins and sea cucumbers, have now been reported. The database presented here should be continuously updated and improved. It is of paramount importance to resume the collection of landing statistics, including information on fishing effort, to assess the relative impact of fisheries and environmental factors on the main Brazilian fishing stocks.

Keywords: fishery statistics, catch, commercial fisheries, small-scale, large-scale, threatened species

\section{INTRODUCTION}

An analysis of the status of several fishery stocks exploited around the globe for which data are available has indicated that about $34.2 \%$ of the stocks are overexploited and another $59.6 \%$ fully exploited (FAO, 2020). Landing data are the most basic information needed to proceed with these assessments and manage fisheries. However, in many regions around the world this information is either not available with satisfactory quality or is simply inexistent. Numerous initiatives have been running in different countries to recover past landing information and generate more comprehensive catch statistics. Their results were compiled in an atlas aiming at portraying global marine catches, which provided fishing data per sector (artisanal, industrial, recreational, and subsistence), a work done by the Sea Around Us (Pauly and Zeller, 2016). More recent studies were conducted to either cover new areas or to update previous reconstructions (see, e.g., Piroddi et al., 2015; Belhabib et al., 2016; Khalfallah et al., 2017; Zeller and Pauly, 2018; Pauly and Liang, 2019). The volume published by Pauly and Palomares (2019) brought more examples of reconstructed databases and emphasized the importance of such reconstructions using hard-to-obtain quantitative data, which may be combined with qualitative information of local experts, leading to better coverage of catch statistics. Similar initiatives have also been pursued toward specifically portraying recreational fisheries, with global catches estimated at 0.9 million tonnes (Freire et al., 2020). This figure, although small when compared to commercial fisheries, has high economic value (Cisneros-Montemayor and Sumaila, 2010).

Several institutions have been in charge of fisheries management in Brazil throughout the years (for a more detailed historical account, see Freire, 2003). From 1990 to 2007, the Brazilian Institute for the Environment and
Renewable Resources (IBAMA) was in charge. After 2007, this responsibility was transferred to SEAP/PR (Special Secretariat for Aquaculture and Fisheries from the Presidency of the Republic, created in 2003), which evolved to the Fisheries and Aquaculture Ministry (MPA) in 2009 (Law N.11958, June 26, 2009). A system of co-management between the MPA and the Ministry of the Environment (MMA) was introduced by this Law, aiming at the sustainable use of fishery resources, under the coordination of the MPA. In 2015, the MPA became extinct, and its responsibilities were passed to the Ministry of Agriculture, Livestock and Supply (MAPA). In 2017, these responsibilities were transferred to the Ministry of Industry, Foreign Trade and Services (MDIC), which became extinct in early 2019. Finally, fisheries management was handed over to the Secretariat of Aquaculture and Fisheries (SAP) in 2019, which is part of the MAPA.

The collection system of landing statistics in Brazil, which was problematic from the beginning, was eventually lost in the middle of this institutional instability (see, e.g., Mendonça, 2018 for more information on causes and consequences of this instability). In 1995, a National System of Information on Fisheries and Aquaculture (SINPESQ) was created (Decree N.1694, November 13, 1995) with the objective of collecting, compiling, processing, analyzing, exchanging, and disseminating information about the national fishing sector. The Brazilian Institute of Geography and Statistics (IBGE) was responsible for coordinating the implementation, development, and maintenance of the SINPESQ. However, this system was never fully functional, notably its landings and production data module. The last national bulletin containing landing statistics for Brazilian marine waters by species for each of the 17 coastal states was published in 2007 (IBAMA, 2007), followed 
by national bulletins for 2008-2011 elaborated by the MPA that contained only landing statistics by species for Brazil as a whole and totals for each state (not separated by species) (MPA, 2012a,b, undated). Currently, only the states of São Paulo, Paraná, and Santa Catarina have online systems of landing statistics, and there is an initiative to standardize the collection system of landing statistics and databases for these three states, as well as for Espírito Santo and Rio de Janeiro. Nationally, the Department of Register and Monitoring of Aquaculture and Fishery, which is part of the SAP, is currently in charge of coordinating the collection system and systematization of data related to aquaculture and fishery in Brazil (Article 32 VII of Decree N.10253, February 20, 2020). There is still no official national database available online containing landing statistics for Brazil.

Freire (2003) initiated a process of encoding landing statistics to make them available to the public at large. The resulting database was restricted to the period 1980-2000, which indicated a decline in landings in the early 1990s. This author also found a discrepancy in data reported in national bulletins and by the Food and Agriculture Organization (FAO) after 1988. A tentative list showing the connection between common names reported in the bulletins and scientific names was presented for the first time, but although it was still not connected to the database. Freire and Oliveira (2007) continued the encoding work, extending the period to 1950-2004. In this new version, a continuous increase in landings was evident from 1950 to 1985 , followed by a decrease in the early 1990s, mostly associated to the sardine crisis, and then an increase from 2000 to 2004 . The discrepancy between the FAO database and national bulletins was eventually solved here, as recreational landings were removed from the FAO database. Those authors were not able to establish a reasonable connection between common and scientific names for all resources caught, which was later done by Freire et al. (2015), when catch reconstruction data were also extended to include the period of 2005-2010. This third and more complete database identified two levels of taxonomic loss, one from state bulletins to national bulletins and another one from national bulletins to the FAO database. The objective of the present work was to reconstruct the national database of marine commercial landings for the Brazilian industrial and artisanal fisheries, from 1950 to 2015.

\section{MATERIALS AND METHODS}

\section{Original National Data Sources and General Definitions}

The database presented here is an updated version of a previous database compiled by Freire (2003) for 1980-2000, and extended by Freire and Oliveira (2007) and Freire et al. (2015) to include the periods of 1950-2004 and 1950-2010, respectively. Specifically, the database compiled by Freire et al. (2015) was revised and extended to include the period between 2011 and 2015 for all 17 coastal states in Brazil, from Amapá to Rio Grande do Sul, representing the entire Brazilian coastline (Figure 1). Commercial landings include those originating from both artisanal and industrial fleets, which was considered as small-

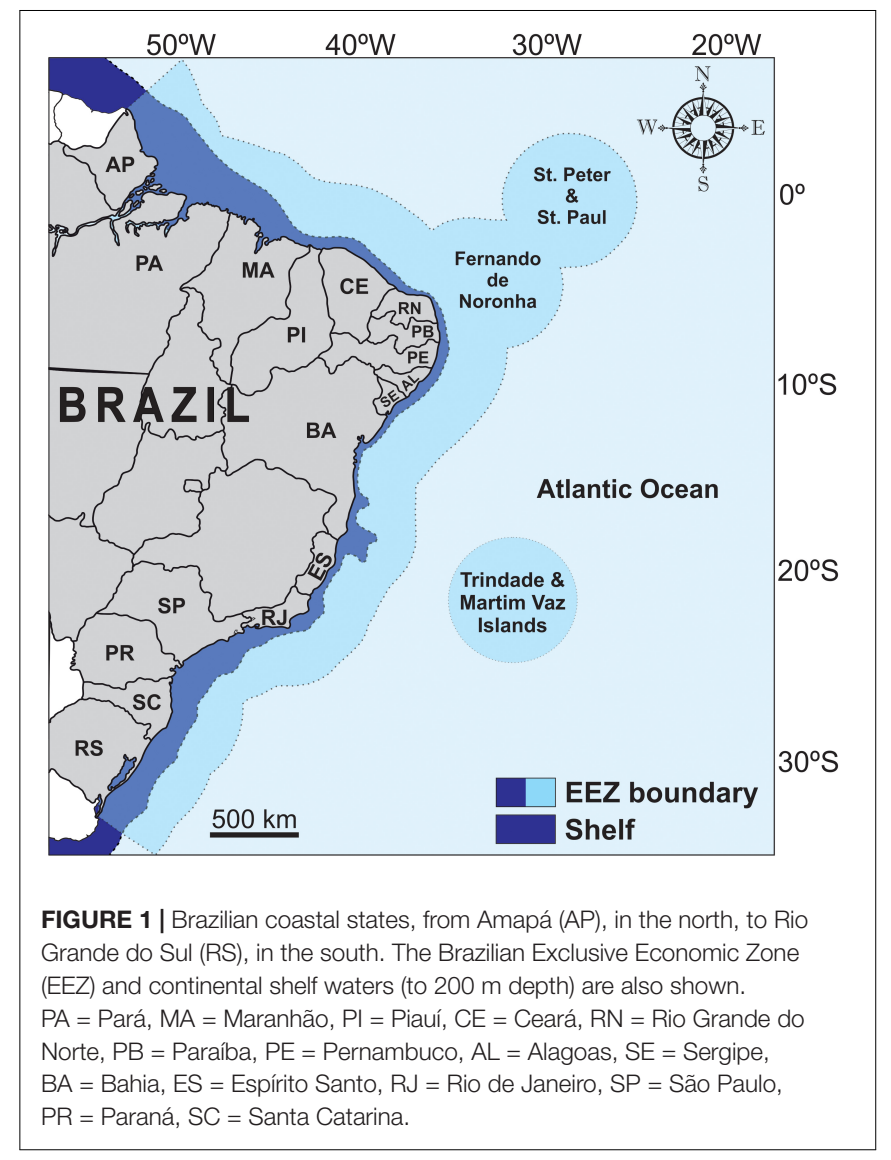

and large-scale, respectively, for the purpose of incorporating into the Sea Around Us global database. The limit between these two fleets is blurry and 20 GT (gross tonnage) has been traditionally considered as a cut-off point in Brazil (see, e.g., Vasconcellos et al., 2007). The Law N.11959' (June 29, 2009), which concerns the National Policy for the Sustainable Development of Aquaculture and Fishery, considers the work regime to separate these two fleet types. It does not cite a specific GT or boat length as limit between these two fleets in its Article 8, but it does include small boats in the artisanal fleet and small, medium, and large boats in the industrial fleet. Additionally, in its Article 10, a definition of small $(\mathrm{GT} \leq 20)$, medium $(20<\mathrm{GT}<100)$, and large boats $(\geq 100 \mathrm{GT})$ is included. The original attribution to artisanal and industrial fisheries used in the national bulletins from 1978 onward was kept in the reconstructed database for most of the records. For previous years, when artisanal and industrial landings were reported together, the average proportion for 1978-1980 was used to reconstruct landings for the earliest years, considering the starting year of industrial fisheries for each species or group of species. The year a given species started being exploited by industrial fisheries in each state was extracted from the literature.

From 1979 onward, landings were reported separately for fresh and marine waters in national bulletins and this separation was followed throughout this study. The mangrove crab, Ucides

\footnotetext{
${ }^{1}$ http://www.planalto.gov.br/ccivil_03/_ato2007-2010/2009/lei/111959.htm
} 
cordatus, was the only case reported in fresh and marine waters in different years. Here, we decided to include this crab, as this is an estuarine species found in the same habitat as other species already included in marine waters in the national bulletins. For 1962-1978, freshwater and marine species were included in the same table. We separated the marine species from the freshwater ones using their common names. For 1956-1961, landings were reported by large groups (fishes, crustaceans, mollusks, mammals, and chelonians). The species composition for the 1962-1964 period was used to split these landings among species. Finally, for 1950-1955, only landings for all groups combined (fishes + crustaceans + mollusks + mammals + chelonians) were reported and the species composition for the 1956-1958 period, identified in the previous step, was used to split landings among species. This process was repeated separately for each of the 17 Brazilian coastal states. Note that some of these methodological steps were not needed for the state of São Paulo, due to an early construction of a landing database (for additional information for this state, see below). More detailed methodological steps can be found in the references above-mentioned.

The term "landings" was used throughout this paper to indicate that there was no attempt to consider discards. Additionally, catches from recreational and subsistence fisheries were not included here or catches from illegal activities. Landings have been reported in official national bulletins by common name. The correspondence between common and scientific names was established preferentially based on local references (see, e.g., Furtado and Nascimento, 1982; Freire and Pauly, 2005; Thomé-Souza et al., 2014a; Santos et al., 2019), as the same common name can refer to different species in different parts of the country. Most of the correspondence was kept as defined in Freire et al. (2015), but in some states where local studies were carried out, this correspondence was improved, including the proportion attributed to different species under the same common name. Additionally, some species names were changed to reflect the results of current studies on molecular and morphological analyses (see, e.g., Menezes et al., 2015; Marceniuk et al., 2019). Our team included experts from 13 out of the 17 Brazilian coastal states to improve this correspondence. Whenever the correspondence to a species was not found, landings were attributed to a genus or a family (or even higher taxonomic level). The species composition of the final database was assessed by a taxonomist who used the most recent updates in species nomenclature following the hierarchy defined by Nelson et al. (2016). For some states, current data were more detailed in terms of species composition, but no attempt was done to split landings among these species backward when the landings were restricted to few more recent years, as this composition could have changed. When the species composition was available in different periods, the closest proportion was used to split the landings reported by generic common names.

The basis for the country-wide database of marine landing statistics compiled here was the national official bulletins published in Brazil, for the period 1950-2010 (see Freire et al., 2015 for all sources and detailed methodology used). Some problems in the original sources were detected during the reconstruction process and were corrected using local data sources (see, e.g., Valentini et al., 1991, Pezzuto and Borzone, 2004). Additionally, it was detected that total landings for each state provided in different parts of the bulletins were not equal. Thus, landings for the category "pescado não-identificado" (here attributed to "other fishes") were included in the totals for a given state in some parts of the bulletin but not in others in the 1980s. It seems that "unidentified crustaceans" were included in the totals in the first semester but not in the second (two bulletins a year were produced during most of the 1980s). This also happened to mollusks, but more rarely. These errors were less common for the states in southern Brazil. All adjustments in the reported landings for the years 1950-1961, 1965, and 2008-2010 made by Freire et al. (2015) were maintained, including the replacement of repeated values for all years between 1990 and 1995, based on the mean value calculated for 1997-1999, by linear trends. Even though national bulletins were available for the years 20082011 (MPA, 2012a,b, undated), they did not provide landing data per species for each coastal state. There was no national bulletin produced after 2011. For more recent years (2008-2015), due to the absence of landings by species for each state, we used different data sources to complete the time series (Table 1). The estimation process was very heterogeneous and depended on the availability of data for more recent years and the level of expertise and availability of the personnel involved in the estimation. The reconstruction is a very long process and occurred in different time periods for each state.

Landings of freshwater fish and crustacean species were reported together with marine and estuarine species in the states of Rio Grande do Norte, Sergipe, Bahia, São Paulo, and Paraná. These values were not included in the reconstructed database, but it is worth pointing out that local fishers may be improving their financial gains by either making some incursions inland or by catching freshwater species inhabiting estuarine waters.

\section{Detailed Reconstruction Process for Each State}

For a complete description of data availability, see Table 1. The northern region includes the states of Pará and Amapá (Figure 1). No landing data were available for these states in 2011-2015 and a 3-year running average was used. The northeastern region includes nine states: Maranhão, Piauí, Ceará, Rio Grande do Norte, Paraíba, Pernambuco, Alagoas, Sergipe, and Bahia. The data for Rio Grande do Norte relied upon information collected by IBAMA between 2000 and 2010, which was then provided to the researchers upon request. IBAMA collected data on 22 coastal municipalities, covering the entire state. Data for 2011 and 2014 were provided by Petrobras, a Brazilian oil company, for nine municipalities on the northern coast of the state, as part of a monitoring program in regions subject to possible impacts of offshore oil platforms (Damásio et al., 2020). One municipality on the eastern coast of the state (Baía Formosa) was sampled by the research team between 2013 and 2014 (Damasio et al., 2016). Thus, data from these different sources were combined and proportionality of landings for different municipalities as well as linear interpolation were used for missing data. For Sergipe, data for 2011-2015 for each species were extracted 
TABLE 1 | Type of data available to proceed with the reconstruction of landings for Brazilian marine waters for the period 1950-2015.

\begin{tabular}{|c|c|c|c|c|c|c|c|c|c|c|c|c|c|c|c|c|c|}
\hline Years & AP & PA & MA & PI & CE & RN & PB & PE & $A L$ & SE & BA & ES & RJ & SP & PR & sc & RS \\
\hline 1950-1955 & TotalB & TotalB & TotalB & TotalB & TotalB & TotalB & TotalB & TotalB & TotalB & TotalB & TotalB & TotalB & TotalB & TotalB & TotalB & TotalB & TotalB \\
\hline 1956-1961 & GroupB & GroupB & GroupB & GroupB & GroupB & GroupB & GroupB & GroupB & GroupB & GroupB & GroupB & GroupB & GroupB & GroupB & GroupB & GroupB & GroupB \\
\hline 1962-1975 & SpRB & SpRB & SpRB & SpRB & SpRB & SpRB & SpRB & SpRB & SpRB & $\mathrm{SpRB}$ & SpRB & SpRB & SpRB & SpRB & SpRB & SpRB & $\mathrm{SpRB}$ \\
\hline 1976-1977 & $\mathrm{SpHB}$ & $\mathrm{SpHB}$ & SpHB & SpHB & SpHB & $\mathrm{SpHB}$ & SpHB & $\mathrm{SpHB}$ & SpHB & SpHB & SpHB & SpHB & SpHB & $\mathrm{SpHB}$ & SpHB & $\mathrm{SpHB}$ & SpHB \\
\hline 1978-1979 & SpB & $\mathrm{SpB}$ & SpB & SpB & $\mathrm{SpB}$ & SpB & SpB & SpB & $\mathrm{SpB}$ & $\mathrm{SpB}$ & $\mathrm{SpB}$ & $\mathrm{SpB}$ & $\mathrm{SpB}$ & $\mathrm{SpB}$ & $\mathrm{SpB}$ & $\mathrm{SpB}$ & $\mathrm{SpB}$ \\
\hline 1980-1989 & SpM & SpM & SpM & SpM & SpM & SpM & SpM & SpM & SpM & SpM & SpM & SpM & SpM & SpM & SpM & SpM & SpM \\
\hline 1990-1994 & SpMRp & SpMRp & SpMRp & SpMRp & SpMRp & SpMRp & SpMRp & SpMRp & SpMRp & SpMRp & SpMRp & SpMRp & SpMRp & SpMRp & SpMRp & SpMRp & SpMRp \\
\hline 1995-2007 & SpM & SpM & SpM & SpM & SpM & SpM & SpM & SpM & SpM & SpM & SpM & SpM & SpM & $\mathrm{SpM}$ & $\mathrm{SpM}$ & SpM & SpM \\
\hline 2008 & None & None & None & None & SpM & SpM & None & None & None & None & None & None & SpM & SpM & None & SpMl & SpM \\
\hline 2009 & None & None & None & None & None & SpM & None & None & None & None & None & None & SpM & SpM & None & SpMl & SpM \\
\hline 2010 & None & None & None & None & None & SpMl & None & None & None & SpM & None & None & SpM & SpM & None & SpMl & SpM \\
\hline 2011 & None & None & None & None & None & SpMl & None & None & None & SpM & SpMP & SpMP & SpM & SpM & None & SpMl & SpM \\
\hline 2012 & None & None & None & None & None & SpMl & None & None & None & SpM & SpMP & SpMP & SpM & SpM & None & SpMI & None \\
\hline 2013 & None & None & None & None & None & None & None & None & None & SpM & SpMP & SpMP & SpM & SpM & None & SpMl & None \\
\hline 2014 & None & None & None & None & None & None & None & None & None & SpM & SpMP & SpMP & SpM & SpM & None & SpMl & None \\
\hline 2015 & None & None & None & None & None & None & None & None & None & SpM & SpMP & SpMP & None & SpM & None & SpMl & None \\
\hline
\end{tabular}

None of the national bulletins published by the Ministry of Fisheries and Aquaculture (MPA) available for the period 2008-2011 were used here, as there was no detailed information by species for each state. Additionally, we present the type of data available for some states from other sources for the period 2008-2015. All data sources used to replace landing data from national bulletins or to cover the most recent years are provided in the reconstructed database that will be made available online at the webpage of the Instituto de Pesca.

TotalB (both), only total landings for each state provided (both marine and freshwater together, not separated into artisanal and industrial); GroupB (both), landings per group (fishes, crustaceans, mollusks, mammals, and chelonians) (both marine and freshwater together, not separated into artisanal and industrial); SpRB (reduced/both), landings only for a reduced number of main species (both marine and freshwater in the same table; not separated into artisanal and industrial); SpHB (higher/both), landings per species for a higher number of species, representing 75-80\% of total landings (both marine and freshwater in the same table; not separated into artisanal and industrial); SpB (both), landings per species (both marine and freshwater in the same table; separated into artisanal and industrial); SpM (marine), landings per species for the marine habitat (separated into artisanal and industrial); SpMRp (marine/repetition), there was no system of data collection in Brazil during this period (except for a few main species for which there were working groups) and a mean for the previous 4 years was calculated for each of all other species and printed in the national bulletin (separated into artisanal and industrial); SpMI (marine/industrial), landings per species for the marine habitat (only for industrial fleet); SpMP (marine), landing per species for some municipalities (partial); a regional approach was used to extrapolate for the region and then to the state; None, there was no collection system in that state for those years and the Ministry of Fisheries and Aquaculture (MPA) published bulletins where a general estimation procedure was used to estimate only total landings for each state in 2008-2011, but no landing data per species for each state was estimated. 
from local bulletins (Thomé-Souza et al., 2013, 2014a,b; Araújo et al., 2016). These bulletins were produced during monitoring programs of oil activities. For Bahia, landings between 2011 and 2015 were available only for some municipalities in five different administrative regions and the proportionality of annual landings per species inside regions was used to estimate missing values for other municipalities and years. This regionalized approach allowed to extrapolate total landings for each region and then to the state. For the remaining states, a 3-year running average was used to estimate landings for 2011-2015.

The southeastern region encompasses the states of Espírito Santo, Rio de Janeiro, and São Paulo (Figure 1). For Espírito Santo, most of the data previously estimated by Freire and Oliveira (2007) were used, but some corrections/inclusions were made. Landing data for each species for the period 2013-2014 were reconstructed applying LOESS (locally weighted scatterplot smoothing) models or linear cubic spline interpolation on the available time series through information provided in spreadsheets and reports produced by the Program of Fishery Statistics of Espírito Santo (Programa de Estatistica Pesqueira do Estado do Espírito Santo) developed from monitoring programs of oil, gas, and ports activities (Hostim-Silva and Scheidt, 2013). For Rio de Janeiro, data previously estimated by Freire and Oliveira (2007) were also used, with some corrections and inclusions. Landing data for each species for the period 2008-2010 were reconstructed through information provided in spreadsheets by municipalities such as Angra dos Reis, Paraty, Arraial do Cabo, and Cabo Frio (unpublished data), spreadsheets and reports produced by the Fishing Institute of the state of Rio de Janeiro (FIPERJ/MPA/UFRJ, undated; FIPERJ/Prefeitura Municipal de Cabo Frio, undated) and of São Paulo (PMAP/Instituto de Pesca de São Paulo, 2014), and spreadsheets from monitoring programs of oil and gas activities (Petrobrás, undated). Missing values of some species in the middle of the time series were filled using linear interpolation as done for other states.

For the state of São Paulo, a different procedure was possible as some co-authors have been responsible for the state landing data collection since the 1990s. Landing information was available for the years 1944 (Vieira et al., 1945), 1959-1965 (Braga et al., 1966), and 1969-2015 (ProPesq institutional database, Ávila-da-Silva et al., 1999). All fishery-related information available after 1959 was obtained through dockside interviews with fishers, using census, and through records from fishing industries. There has been no interruption in the data collection system of São Paulo since 1959. A more recent description of the monitoring system of landing statistics is available in Carneiro et al. (2016, 2018), and Mendonça (2018). Although the information gathered by the state of São Paulo was forwarded to the federal government for the composition of the national fisheries statistics, the federal government did not use it in its original form. Landing data for some species were grouped into broader common names and, for the period 1990-1994, the original forwarded data were replaced by averages for 1986-1989, according to the methodology adopted by the federal government in that period for all other states. Landing reconstruction for the period with missing values (1950-1958 and, for some species, for the
1966-1968 period) was performed by species applying LOESS models or linear cubic spline interpolation on the available time series. Landings for 1950-1958 were estimated considering data for 1944 and 1959-1965 as anchor points, while landings for 1966-1968 were estimated based on 1959-1965 data and from 1969 onward. For landings from 1990-1994, the averages adopted by the federal government were replaced by the revised original dataset previously sent and ignored. Categorization into artisanal and industrial fleets for these early years was done considering the year when the industrial fishery started for that species or group of species, known from other sources, and the proportion of landings shared by artisanal and industrial fisheries available for the earliest years, as done in other states.

The southern region includes the states of Paraná, Santa Catarina, and Rio Grande do Sul (Figure 1). The collection of landing statistics for the state of Paraná, interrupted in 2008, was resumed in 2016 through PMAP-PR (Jankowsky et al., 2019), and these current data were used to revise data from 2008 to 2010 and to interpolate values for 2011 to 2015 using a linear cubic spline interpolation applied to the available time series. The same procedure was possible for the state of Santa Catarina, specifically for artisanal fisheries. Although Santa Catarina did not interrupt the collection of fishery statistics for the industrial fleet, it stopped collecting data for artisanal fisheries between 2008 and mid-2016. A non-linear time structured estimation procedure was used for 2011-2015. For Rio Grande do Sul, no complete dataset was available for the period analyzed and a 3-year running average was used. After the completion of the reconstruction for all states, a national reconstructed database was created.

We were not able to reconstruct time series for individual species or group of species to the point of accounting for all landings reported for each state and this may have resulted in slightly smaller reconstructed values. On the other hand, reconstructed landings for some years were higher due to the replacement of original values by those from publications by local experts who analyzed data for some species or group of species into more detail. These publications are documented in the reconstructed database made available through the website of the Instituto de Pesca².

\section{Statistical Analyses}

Landing data for each state were manipulated in Microsoft Excel files, where different sheets were used for each species or group of species. In these files, the correspondence between common and scientific names was established and changes in common names through time could be detected. Simple linear regressions were fitted in MS Excel and statistical significance of some important trends observed were assessed using an analysis of variance for the linear regression. The slope $(b), F$-value, $p$-value, and coefficient of determination $\left(r^{2}\right)$ were presented for these regressions. A significance level of 0.05 was used for these tests. All non-linear estimation processes applied to the time series available were performed using the $\mathrm{R}$ software version 4.0.3. ( $\mathrm{R}$ Core Team, 2020). The functions used were na.kalman included in the library imputeTS (Hyndman and Khandakar, 2008;

\footnotetext{
${ }^{2}$ http://www.propesq.pesca.sp.gov.br/37/conteudo
} 


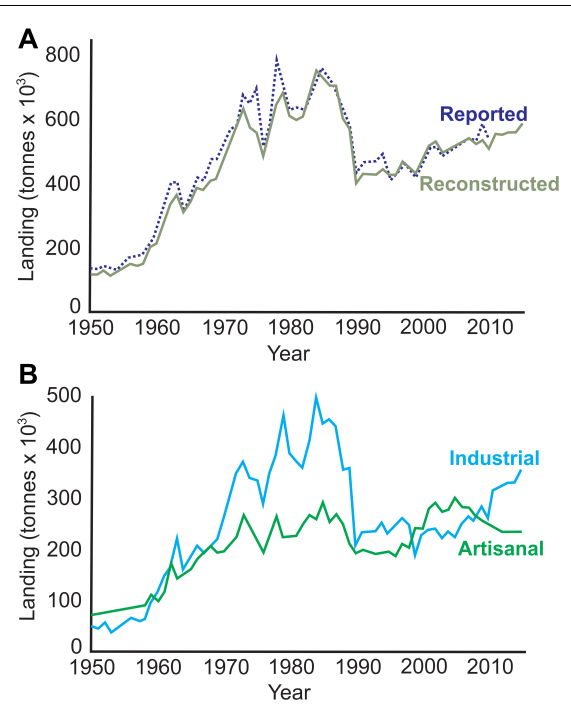

FIGURE 2 | Reported (1950-2011) and reconstructed (1950-2015) landings from Brazilian marine waters (A) and reconstructed landings split into artisanal and industrial fleets for the same period (B). Reported values refer to data directly obtained from national bulletins.

Moritz and Bartz-Beielstein, 2017) and loess already included in the base $\mathrm{R}$ package.

\section{RESULTS}

\section{General Features of the Reconstructed Database}

Our reconstructed database, which included a total of 125,614 records, indicated that landings increased from about 119 thousand tonnes in 1950 to about 755 thousand tonnes in 1984, and abruptly decreased thereafter down to 400 thousand tonnes in 1990 (Figure 2A). After that year, landings started to increase again, but at a much lower rate, reaching 587 thousand tonnes in 2015. Reconstructed landings are still lower than reported landings, mainly for the first years. The increasing trend evidenced from 1950 to 1984 was observed for both fleets (artisanal and industrial), as well as the decreasing trend from 1985 to 1990 (Figure 2B). However, most of the national decreasing trend during this period was due to the industrial fleet. Industrial landings have steadily increased their landings in about 8,500 tonnes.year ${ }^{-1}$ from 1999 onward $(F=102.5$; $p<0.0001$; $\left.r^{2}=0.87\right)$. Conversely, artisanal landings have been decreasing about 6,800 tonnes year $^{-1}$ since $2005(F=92.4 ; p<0.0001$; $\left.r^{2}=0.91\right)$.

The analysis by region indicated that artisanal landings were higher in the northern and northeastern regions (Figure 3). In the southeastern and southern regions, industrial landings were on average 2.7 and 4.6 times higher than artisanal landings, respectively (Figure 3). The recording system for the industrial fleet has always been better, as their landings are concentrated in fewer ports. Industrial landings increased at the beginning

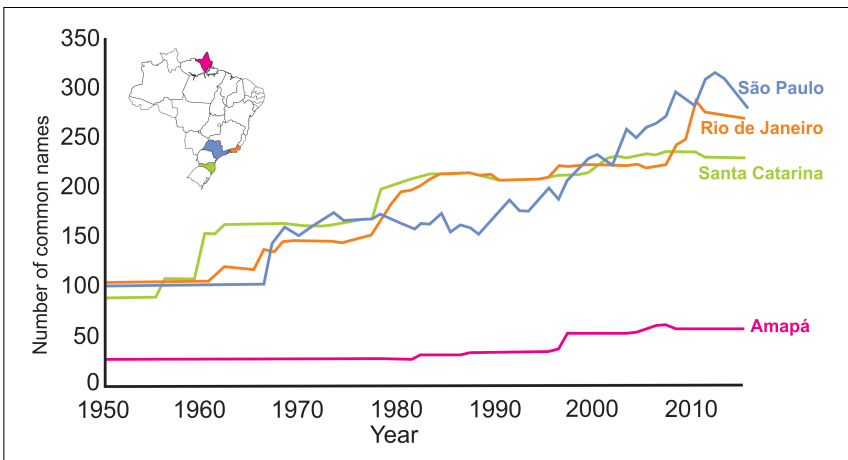

FIGURE 4 | Number of common names reported in the reconstructed landing database of marine commercial fisheries for four Brazilian coastal states (1950-2015): Amapá, with almost no change during the time period analyzed and the states of Rio de Janeiro, São Paulo, and Santa Catarina where an increase in the number of common names was observed. All other states were between these two extremes (not shown).

of the series in the southeast and then declined sharply in 1984, reaching values 4.3 times lower in the 1990s. From 1990 onward, industrial landings remained stable at low levels in the southeast, with a slight increase in the last years of the time series. A similar downward trend was also observed in artisanal landings in the southeast, with an additional downward trend of about 2,690 tonnes year $^{-1}$ from 2005 onward, which may be an alert signal $\left(F=159.5 ; p<0.0001 ; r^{2}=0.95\right)$. The trends in industrial and artisanal landings in the south were similar to those observed in the southeast, except that its industrial landings started declining earlier, in about 3,400 tonnes year ${ }^{-1}$ between 1973 and $2000\left(F=36.7 ; p<0.0001 ; r^{2}=0.59\right)$. After that year, industrial landings started to increase back to the magnitude observed in the 1970s. For artisanal fisheries, landings remained low from 1990 onward (around 22,000 tonnes $\cdot$ year $^{-1}$ ). The largest decrease observed in Brazilian landings was mainly determined by the decreasing trend in the southeastern region (Figure 3 ).

\section{Species Landed}

About 730 common names were identified here, after combining information from the original bulletins with all other sources used in the reconstruction process. An analysis by state indicated that the highest number of common names was observed in the states of Rio de Janeiro, São Paulo, and Santa Catarina, and these numbers increased in the last years, mostly reflecting improvement in the recording system (Figure 4). These are the states that somehow kept a collection system of landing statistics after 2007. Conversely, the state of Amapá had the lowest number of common names reported. Note the high number of common names already in the beginning of the time series of reconstructed data. The attempt to establish a correspondence between common and scientific names resulted in 477 taxonomic units (species, genus, family, order, or higher).

\section{Fishes}

The highest industrial landings were, by far, represented by the "sardinha verdadeira," Sardinella brasiliensis, a species that underwent a sharp decline in the late 1980s and slightly higher 


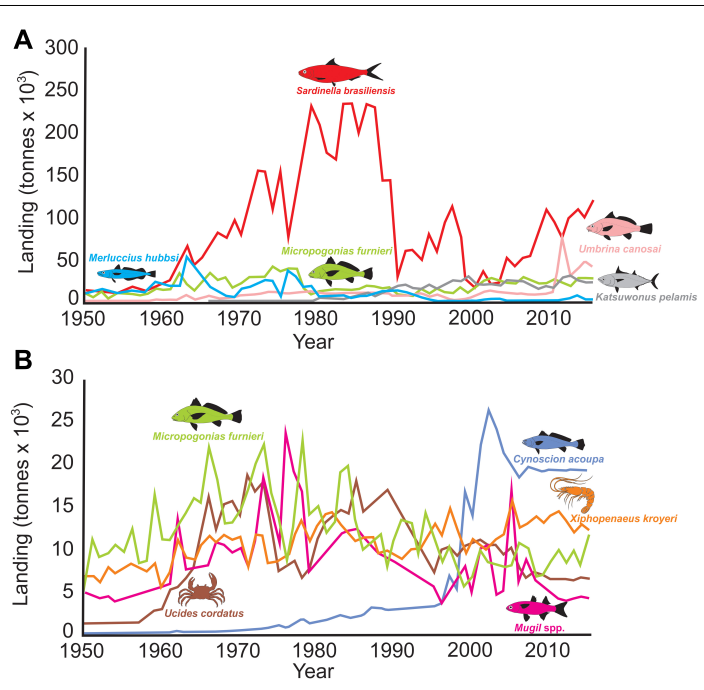

FIGURE 5 | Landing for the top five species in tonnage caught by industrial (A) and artisanal (B) fisheries in Brazil (1950-2015). Note the different $Y$-scales used for industrial and artisanal fisheries.

landings from 2000 onward (Figure 5A). Clearly, its decline was responsible for the total decline in Brazilian landings presented in Figure 2. During the study period, the states of Rio de Janeiro, Santa Catarina, and São Paulo were responsible for $99.7 \%$ of sardine landings, but in the last 3 years Santa Catarina and Rio de Janeiro dominated (91\%). In 2015, landings from Santa Catarina surpassed those from Rio de Janeiro. Finally, landings for S. brasiliensis originated mostly from the industrial fleet throughout the period analyzed, representing 99\% in the last 3 years. Two species showed increased landings during the time series: Katsuwonus pelamis, which has been increasing since the 1980s, and Umbrina canosai, which has been increasing since 2010. Landings of Merluccius hubbsi, which is a resource mostly landed in the state of Rio Grande do Sul (93\%), decreased from 1980 onward to about 7\% of its highest value observed in 1963. Finally, Micropogonias furnieri had relatively stable landings from 1950-2015, being reported in almost all Brazilian states. Landings from Rio Grande do Sul, which dominated during the first 27 years of the time series, decreased in the 1980s and have been surpassed by those from the state of Santa Catarina (currently 3.9 times higher than those from Rio Grande do Sul). This increase in landings recorded in Santa Catarina was mostly due to the partial migration of the industrial fleet from Rio Grande do Sul to the municipality of Itajaí, in Santa Catarina.

Landings from the artisanal fleet were more homogeneous and the top five species were Cynoscion acoupa, Micropogonias furnieri, Mugil spp., U. cordatus, and Xiphopenaeus kroyeri (corresponding to 1.4 to $2.6 \%$ of total landings from 1950 to 2015; Figure 5B). Except for C. acoupa, all species showed an increase in landings from 1950 to 1980 and a decrease thereafter. Landings of C. acoupa increased by $620 \%$, from 1.7 thousand tonnes in 1996 to 22.0 thousand tonnes in 2002, and decreased after that, reaching 16.5 thousand tonnes in 2007. Most of the landings were reported by the state of Pará (in the Amazon area in the northern region), followed by the state of Maranhão (in the northeastern region, but bordering the Amazon area), and originated mainly from artisanal fisheries. In the absence of a system to collect landing statistics for each of these states, a running average of landings was used for the period after 2007 and thus the actual current trend for this species is unknown.

Additionally, we described here some features of other resources with high landing volume, monetary, or social value, or which are under some degree of threat. Lutjanus purpureus
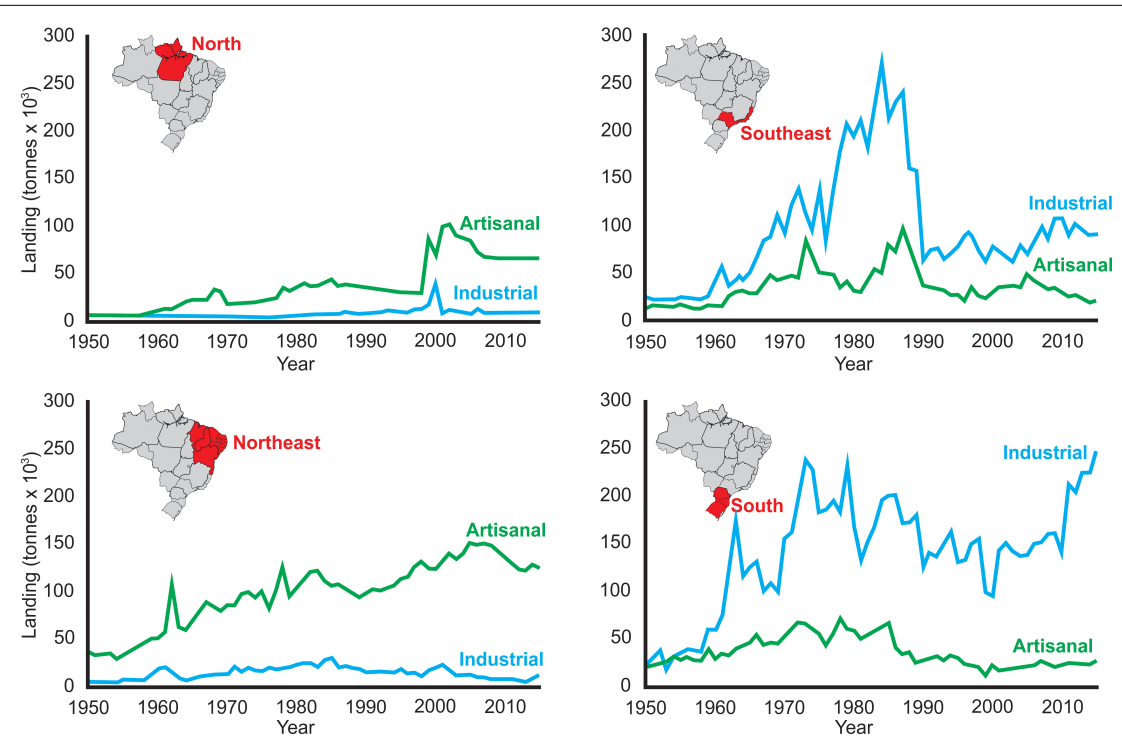

FIGURE 3 | Landing originating from artisanal and industrial fleets in 1950-2015, for the four coastal Brazilian regions: north (states of Amapá and Pará), northeast (Maranhão, Piauí, Ceará, Rio Grande do Norte, Paraíba, Pernambuco, Alagoas, Sergipe, and Bahia), southeast (Espírito Santo, Rio de Janeiro, and São Paulo), and south (Paraná, Santa Catarina, and Rio Grande do Sul). 


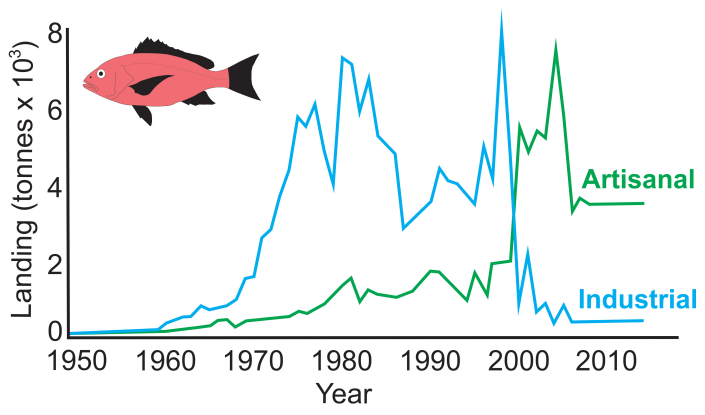

FIGURE 6 | Landing for Lutjanus purpureus in Brazilian marine waters by fleet type (1950-2015).

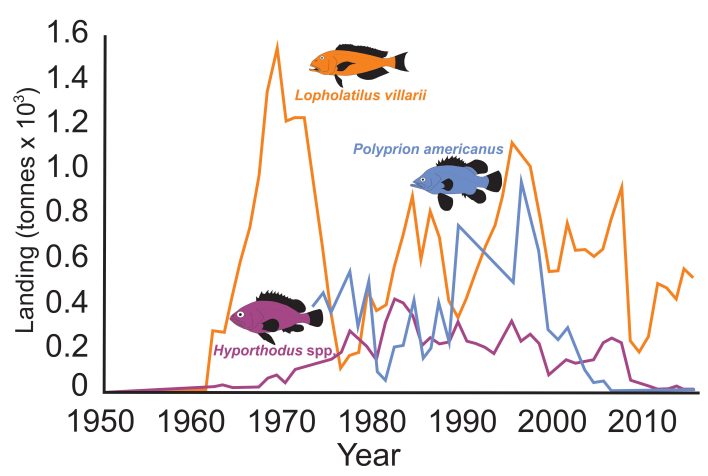

FIGURE 7 | Landing for three selected taxa of demersal fishes in southeastern-southern Brazil (1950-2015).

(southern red snapper; locally known as "pargo") is one of the main fishery resources in northern-northeastern Brazil. The reconstructed database showed a strong decline in their industrial landings from 7,916 tonnes in 1999 to 394 tonnes in 2007. A corresponding increase in artisanal landings was observed, which is currently 8.1 times higher than industrial landings (around 3,450 tonnes; Figure 6). The main state reporting landings for this species was Ceará, but a strong decline has been observed there since 1981. After 1996, the state of Pará has reported increasing landings, which surpassed those from Ceará as early as 1997. Unfortunately, these states have not kept a statewide collection system that would have allowed an assessment of this species' recent trends.

Landings reported for Polyprion americanus (wreckfish, locally known as "cherne poveiro"), Hyporthodus spp. (including Hyporthodus niveatus, snowy grouper or "cherne verdadeiro"), and Lopholatilus villarii (tile fish or "peixe-batata") were mainly originated from the fleet based in the southeastern-southern regions (about $74 \%$ ). In this region, $87 \%$ of landings were from the industrial fleet, mainly from the states of Rio de Janeiro, Santa Catarina, Rio Grande do Sul, and São Paulo. In the early 2000s, after a boom-and-bust cycle, landings of $P$. americanus collapsed. In the last decade, its landings totaled about $2 \%$ of those in the previous decade. Similarly, landings of Hyporthodus spp. in the last 8 years corresponded to about $15 \%$ of those in the previous

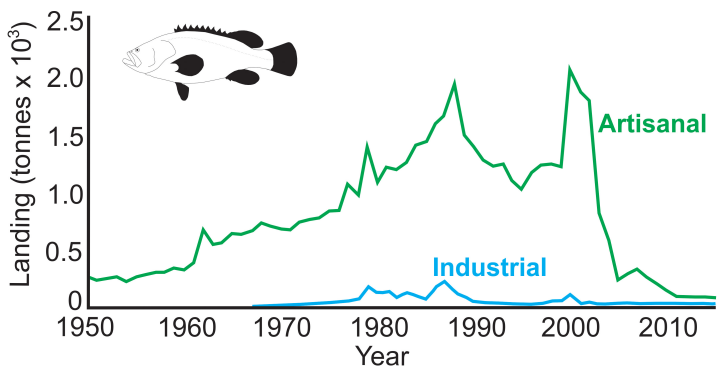

FIGURE 8 | Landing for Epinephelus itajara in Brazilian marine waters by fleet type (1950-2015).

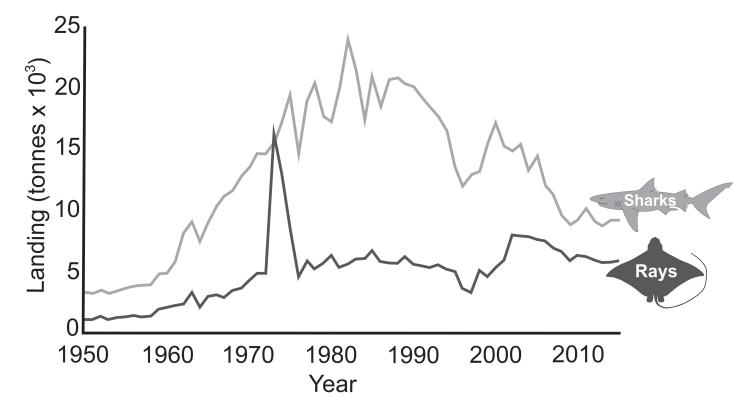

FIGURE 9 | Landing for sharks and rays in Brazilian marine waters (1950-2015).

period. Finally, there was a decrease of $80 \%$ in the landings of L. villarii in southeastern-southern Brazil from 2007 to 2009, but they increased again, reaching 512 tonnes in 2015 (Figure 7). The capture of Epinephelus itajara (Atlantic goliath grouper, locally known as "mero") was banned in 2002 and should retain the same status until 2023, according to current legislation. Its landings, mainly originated from artisanal fisheries, increased steadily until 1988 (1,912 tonnes; Figure 8). This was followed by a decrease and another higher peak in 2000. In 2003, right after the ban, landings were reduced to $40 \%$ of the 2000 value (2,048 tonnes in 2000) and to $4 \%$ in 2011. Currently, artisanal landings are similar to those originating from industrial fisheries. Most of the landings were reported for the states of Pará, Maranhão, and Santa Catarina. Annual landings for both fleets have been around 111 tonnes in the last 5 years of the time series analyzed.

Landings of sharks have always been higher than for rays and have shown a continuous decline since 1982 (Figure 9), reaching around $40 \%$ of its peak in the last 5 years (around 9,200 tonnes). Despite the existence of 37 common names recorded in the national database using the generic term "cação," followed by a more specific common name, e.g., "azul" (for blue shark), the vast majority of landings was recorded only by the generic term "cação" (shark) or "caçonete" (small shark). A total of 19 genera were reported here: Alopias, Carcharhinus, Carcharias, Galeocerdo, Galeorhinus, Ginglymostoma, Hexanchus, Isurus, Lamna, Mitsukurina, Mustelus, Notorynchus, Prionace, Pseudocarcharias, Rhizoprionodon, Scyliorhinus, Sphyrna, Squalus, and Squatina. No attempt to account for catches 


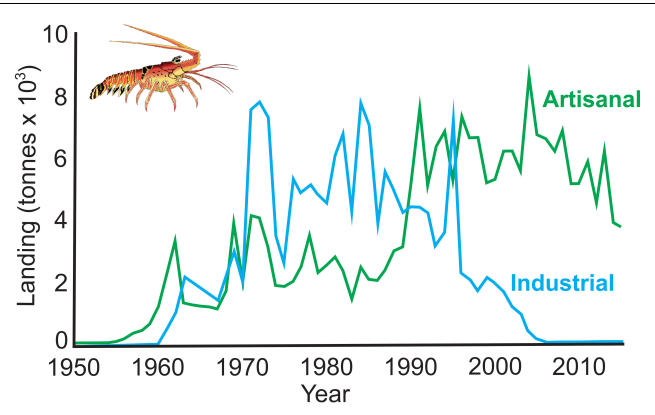

FIGURE 10 | Landing for lobsters (all species) by fleet type in Brazilian marine waters (1950-2015).

associated to finning was made here. Landings for rays increased in the beginning of the time series, kept stable in the 1980s and 1990s, but have been declining since 2002. Exceptionally high landings were observed in 1973-1975, mainly due to records available in the 1973 and 1975 (national bulletins). Similarly, even though 14 common names comprising the generic terms "raia" or "arraia" (ray) were accompanied by specific terms, such as "pintada" (spotted), most of the landings were under the term "arraia." A total of 12 genera were reported in the reconstructed database: Aetobatus, Atlantoraja, Bathyraja, Dipturus, Gymnura, Hypanus, Mobula, Myliobatis, Pristis, Pseudobatos, Pteroplatytrygon, and Rhinoptera.

\section{Crustaceans}

Lobsters represent one of the main fisheries in northeastern Brazil, due to its high market value. Their landings (both artisanal and industrial) totaled about 12,500 tonnes in 1995 (Figure 10). Despite its importance, there were cases where no distinction among species was made, and landings were reported for Panulirus spp. ("lagosta"). Lobster landings are currently almost exclusively artisanal, and they have been decreasing since 2004. Landings for Panulirus argus represented around $73 \%$ of all landings identified by species throughout the period analyzed, followed by Panulirus laevicauda. Highest landings were observed in the states of Ceará, Rio Grande do Norte, and Bahia, all of them following the same decreasing trend. In more recent years, landings reported by the state of Pará have increased and this should be better investigated with current local data. Scyllarids were also caught in Brazilian waters (mostly Scyllarides brasiliensis - 89\% in weight, followed by Scyllarides deceptor, Scyllarides delfosi, and Scyllarides spp.). Their landings were always below 125 tonnes, except for two outliers in the early 1980s.

Landings reported for $U$. cordatus (mangrove crab; locally known as "caranguejo-uçá") were the highest among crabs, yet it has showed a decline since the early 1980s (Figure 11). Despite the occurrence of records from the states of Amapá to Santa Catarina, this crab was mainly caught in the states of Pará, Maranhão, and Piauí. A similar decline was also observed for Cardisoma guanhumi (mostly caught in the states of Bahia, Sergipe, and Pernambuco, but with some records from the states of Ceará down to São Paulo). Landings in Bahia and Sergipe

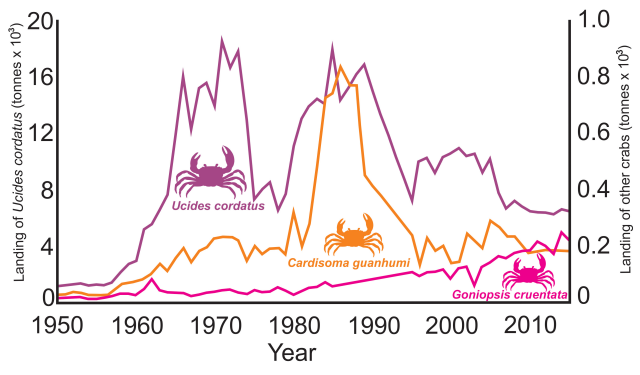

FIGURE 11 | Landing for the main crabs caught in Brazilian waters (1950-2015). Note the different scales for Ucides cordatus and the other crab species.

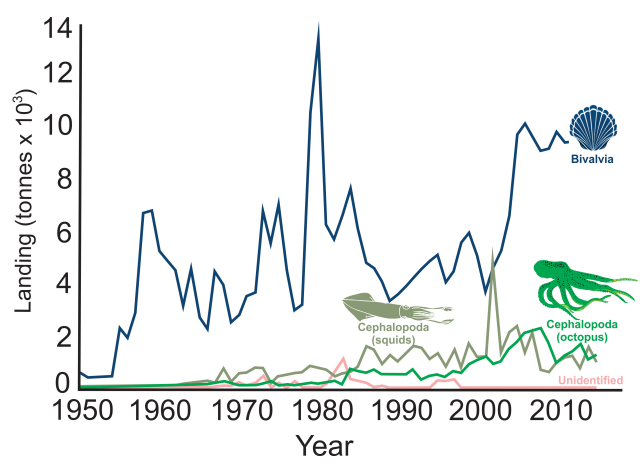

FIGURE 12 | Landing for the main mollusks caught in Brazilian waters (1950-2015).

decreased enormously. The maintenance of the landings level in current years may be biased due to the absence of collection system for many of these states. Landings for Goniopsis cruentata have increased since the 1980s and have surpassed landings for C. guanhumi in the last years.

Landings for Stomatopoda were reported for the state of Rio de Janeiro as early as 1992, reaching about 6.6 tonnes in 2013-2015 (industrial fleet). This group was reported for the state of São Paulo as early as 1968, with records up to 2015 (average $=0.5$ tonnes; both artisanal and industrial fleets).

\section{Other Groups}

Among the mollusks, Bivalvia had the highest landings, which peaked at 13,280 tonnes in 1980 and has currently stabilized around 9,500 tonnes year ${ }^{-1}$ (Figure 12). The following species are caught in order of volume extracted: Mytella spp. (includes Mytella strigata and Mytella guyanensis), Anomalocardia flexuosa, Crassostrea spp. (includes Crassostrea rhizophorae and Crassostrea brasiliana), Euvola ziczac, Perna perna, Phacoides pectinatus, and Tagelus plebeius. The second group were the squids, which included Doryteuthis pleii, Doryteuthis sanpaulensis, Illex argentinus, Lolliguncula brevis, and Semirossia tenera, and had landings of about 1,176 tonnes.year $^{-1}$ in the last 5 years (2011-2015) (Figure 12). In the third group were the octopuses, which have been increasingly caught since 1993, reaching about 1,353 tonnes.year ${ }^{-1}$ in 2011-2015 (Figure 12). 
This group includes Eledone gaucha, Eledone massyae, Octopus insularis, Octopus tehuelchus, and Octopus vulgaris. The lowest landings were for Gastropoda, which started in 1990 and were never higher than 5 tonnes.year ${ }^{-1}$, except for 2001 and 2002, when 42 and 53 tonnes were caught, respectively. Gastropods were represented by Stramonita haemastoma, Strombus spp., and Zidona dufresnei. In all groups, landings were reported under higher taxa in some cases. Landings for sea-urchins (Echinodermata) were reported for the first time in a landing database in Brazil for São Paulo: $4 \mathrm{~kg}$ of Echinometra lucunter caught by artisanal fishers in 2011. Whale and turtle fisheries were banned in Brazil and their landings reached zero in 1986 and 1989, respectively, and will not be discussed here.

\section{DISCUSSION}

\section{General Features of the Database}

The general trend in the data is similar to that found by Freire et al. (2015), as most of the data are the same, except for minor corrections. In addition to Freire et al. (2015), other studies have already analyzed long term series of landings in Brazil, such as Abdallah and Bacha (1999), Dias-Neto (2010), Vasconcellos et al. (2011), and Viana (2013). However, contrarily to these studies, the present reconstruction dealt with a much longer time series, included both industrial and artisanal fleets, and reconstructed time series for all fishing resources, not only the main ones, resulting in an electronic database. The main feature of the reconstruction presented here is showing that, except for the beginning of the time series, when many industrial fisheries had not started yet, artisanal landings were always lower than their industrial counterpart. However, between 2000 and 2007, artisanal landings increased and then overcame those by the industrial fleet. After 2007, artisanal landings started declining, a trend that has been maintained since then. Decline in artisanal landings is worrisome given the large number of fishers who depend on these fisheries (more than one million fishers; Pereira et al., 2012). This declining trend was observed in northern, northeastern, and southeastern Brazil. Although overfishing cannot be discarded, a poor or absent collection system could also explain the figures found here. The gradual abandonment of data collection after 2007 particularly affected artisanal fisheries, as they are much more spread than industrial ones, which facilitates the data collection for the latter. The higher artisanal landings observed prior to 2007 were mainly associated to the landings from the state of Pará (in northern Brazil). A very sharp increase observed in the artisanal landings from that state in 1999 has been mostly attributed to a sampling bias (Isaac et al., 2008). Some future review of Parás data will certainly imply in changes in this 9-year period when artisanal landings surpassed the industrial ones countrywide.

Conversely, some specificities could help to explain the increasing industrial landings from 2000 onward, such as the chartering program of foreign boats concentrated in the southeastern-southern Brazil (see, e.g., Perez et al., 2009). This program aimed at learning new deep fishing techniques due to the overexploitation status of more coastal resources, and at the same time collect information to better manage these deep-water stocks. Indeed, some increase was observed in industrial landings in the southeastern region and, especially, in the southern region. The industrial bottom gillnet fishing fleet based in the state of Santa Catarina (southern Brazil), for example, showed increasing catches between 2001 and 2008 (Pio et al., 2016). The 2000s also coincide with an oil subsidy governmental policy (Arana et al., 2016).

Additionally, there may have been some reallocation of landings between sectors for some states. For the state of Espírito Santo, e.g., landings were reported in national bulletins until 2007 as "artisanal" and "industrial," and were reconstructed as such until 2010. From 2011 onward, the local team working with landing statistics, and who were following the methodology proposed by IBGE (2012), observed that the landings originating from the fleet based in Espírito Santo were all "artisanal" due to the features of the local fishery and fleet (Hostim-Silva and Scheidt, 2013). For Sergipe, some of the larger boats should be considered as "semi-industrial," according to some local experts, but this category was not used here to follow the original classification for most of the states. Clearly, these definitions should be better discussed, and a final classification must be used in future updates of the reconstructed database. However, the artisanal and industrial classification cannot be eliminated, due to the social and economic facets of this activity (Castello, 2010).

The association of scientific names to each common name reported in national and local bulletins is another important feature of the reconstructed database presented here, especially after the government started publishing bulletins with landings associated to common names without identifying the state where those data originated (Dias-Neto and Dias, 2015). Given that common names vary among states, their use without spatial discrimination is a barrier to any kind of stock assessments. The reconstructed database included 477 taxonomic units, but the discussion of the status of each one of them is beyond the scope of this study, with the exception of those that make the bulk of the landings, have high monetary or social value, or are under threat. The number of common names included in the database was already high in the beginning of the time series. However, this reflected the reconstruction procedure, where more detailed information available for some years was used to reconstruct landings for previous years (see Zeller and Pauly, 2018 for a discussion about this issue). The number of common names increased toward the end of the time series analyzed here due to some improvement in the degree of detail for different groups. Using common names is also a problem in the market as, for example, threatened species can be lumped together in broad categories (Cawthorn et al., 2018). During the reconstruction process, the inclusion of experts of different states helped to solve some of the nomenclatural issues. In the absence of local experts, local/regional data or publications were used to find the best correspondence between common and scientific names. Some flaws may still be present in this updated version. Future efforts to refine this database at a regional scale are recommended. Recognizing these difficulties, the MAPA defined the common and scientific names for the main commercially important fish species circulating in the national market in the MAPA Executive 
Order N.53/2020. However, this list still contains many generic terms and ambiguities.

\section{Species Landed}

Sardinella brasiliensis is one of the main cases of collapse in Brazilian waters, whose landings reached the lowest level in 1990, and again in 2000, triggering the establishment of the Committee for Management of Sustainable Use of Sardine in 2005 and the preparation of a plan for the sustainable use of this resource in Brazilian waters in 2011 (Cergole and Dias-Neto, 2011). As a pelagic resource, it is also highly impacted by interannual environmental changes (see, e.g., Soares et al., 2011). Future analysis should include environmental factors as an association with El Niño events was already found (see, e.g., Paes and Moraes, 2007; Soares et al., 2011). Sardine catches increased from 2000 until 2015, but more current data must be analyzed to check if this trend has been maintained. Dias-Neto and Dias (2015) had already called the attention for the fragility of the sardine fishery, which has had longer recovering cycles. According to these authors, landings were larger for Rio de Janeiro, but this changed in the last 4 years of the series analyzed (2011-2015), when landings reported by Santa Catarina were the highest. Here again, an alert is issued that landing port does not necessarily corresponds to the place where the boat is registered, as sardines are landed wherever it is financially better (Dias-Neto and Dias, 2015). Even though this was one of the best studied species in Brazil, its status is considered data deficient by the International Union for Conservation of Nature (IUCN). Sardinella brasiliensis was recently considered synonymous with Sardinella aurita, a cosmopolitan species (Stern et al., 2018), but we opted to wait for further studies before the database is updated.

Some controversy has also been observed around L. purpureus. Some authors consider the occurrence of a second species in northern Brazil (Silva et al., 2020), Lutjanus campechanus, which is difficult to morphologically differentiate from $L$. purpureus. Here, again, the original name, $L$. purpureus, has been maintained until further studies confirm the presence of this second species. The main point here is to emphasize that even a species as $L$. purpureus, which used to be one of the most important fish resources in northeastern Brazil, until it collapsed and had its fishing moved further north (Souza et al., 2008), still lacks an updated complete landing database. This species is not included in the IUCN red list, but it is listed as vulnerable by the Executive Order MMA N. 445/2014 in Brazilian waters.

In terms of fish species, E. itajara represents an emblematic case for being considered the most endangered fish species in the tropical Atlantic (Ferreira et al., 2014). Globally, it is listed as vulnerable by the IUCN. This species presents some of the features that make it especially prone to risk, namely: slow growth and delayed maturity, territorial fidelity, spawning aggregations, and fearlessness to divers (Ferreira et al., 2014). Yet, despite a ban in 2002, extractions were still occurring in Brazilian waters at least until 2011 (Giglio et al., 2014). Here, these extractions have been shown to continue until the end of the time series in 2015, at least in the states of Sergipe and Bahia, where local data were still collected. These states carry two of the spawning aggregations detected by Giglio et al. (2016). Two other areas of aggregation were mentioned in that study: São Paulo-Paraná-Santa Catarina and Pará. Current data for the states of São Paulo and Paraná did not show landings for "mero," which by no means suggest that its fishing does not happen. In the absence of enforcement, unreported landings are a more realistic possibility. Moreover, the state of Santa Catarina stopped the collection system of landing statistics for artisanal fisheries in 2007. As most E. itajara are caught by artisanal fishers, this reconstructed database was not able to capture information for this state after 2007. The collection system for artisanal fisheries in that state has resumed in 2019 and will bring more information in future updates of this database. For the state of Pará, no state-wide system of collection of landing statistics is currently in place. Thus, even though there are spawning aggregations found in the coast of that state (Giglio et al., 2016), again this database was not able to detect whether this species is caught and by how much. Yet, some information in the literature suggests that its fishing is a reality in Pará and in the neighboring state of Maranhão (Pereira et al., 2020). In these states, "mero" is landed in isolated areas, usually at night, and are also headed or sold in pieces to avoid surveillance and enforcement. Hence, they do not show up in official data. All these cases stress the importance of resuming the collection system of landing statistics nationalwide to be able to assess the status of these important resources.

Similarly to E. itajara, P. americanus, $H$. niveatus and L. villarii are highly vulnerable to overfishing due to their long lifespan and late maturity (Ávila-da-Silva and Haimovici, 2005; Haimovici and Peres, 2005; Costa et al., 2012). Globally, P. americanus is listed in the IUCN Red List as data deficient and H. niveatus as vulnerable. Lopholatilus villarii is not listed, but it is considered as vulnerable by the Executive Order MMA N. 445 in Brazilian waters. They have been caught with different types of hook and line techniques, but in the early 1990s, a new technique using steel wire longlines was developed in the state of São Paulo. The use of this gear quickly spread across the southeastern-southern Brazilian coast, considerably increasing fishing effort and catches (Peres and Haimovici, 1998; Ávila-da-Silva et al., 2001). In 1998, the Brazilian fishing authorities implemented a foreign vesselchartering program and many of these vessels were bottom longliners targeting mainly P. americanus (Perez et al., 2009). In 2005, this species was classified as critically endangered, and its capture was prohibited (Executive Order MMA N.37/2005; Executive Order MAP/MMA N.14/2015). The stock assessment for L. villarii indicated a 50\% biomass reduction from 1995 to 2000 (Ávila-da-Silva and Haimovici, 2005). Nevertheless, it was not until 2018 (Executive Order SEAP N.40/2018) that a set of rules came into effect to manage $L$. villarii and $H$. niveatus fisheries. Among the measures adopted were a limited number of fishing licenses, a closed season from September 1st to October 31 st at depths of 100-600 m, and the establishment of minimum catch sizes ( $40 \mathrm{~cm}$ for L. villarii and $45 \mathrm{~cm}$ for H. niveatus).

Elasmobranchs are also prone to overfishing due to some of their life-history traits. Here again their landings are mostly registered under the common names "cação" or "caçonete" (i.e., sharks) and "arraia" or "raia" (i.e., skates or rays). In more recent years, there have been attempts to increase the degree of detail in recording landings, but the improvement is still subtle and 
mostly applies to industrial fisheries. Four shark species recorded in our database are listed by the IUCN as critically endangered: Carcharhinus longimanus, Galeorhinus galeus, Sphyrna lewini, and Sphyrna mokarran. Similarly, two species of rays have been listed as critically endangered (Pristis pectinata and Pseudobatos horkelii) and other two as endangered (Atlantoraja castelnaui and Mobula hypostoma). Temple et al. (2019), when discussing the Indian Ocean situation, stressed the need to improve data collection to properly assess the impact of fisheries on some threatened species, particularly sensitive small and medium sized elasmobranchs caught by local artisanal fishers. As pointed by Iglésias et al. (2010), simply registering species under broad common names has a strong negative impact on the assessment of the status of many species worldwide and the adoption of recovery plans. This issue was also raised by Barreto et al. (2017) for Brazil, which was considered the 11th top producer and 1st importer of shark meat in the world. Some effort has been devoted to improve the identification of rays/skates commercialized in Brazil (see, e.g., Marques et al., 2019).

Lobster landings were dominated by $P$. argus and have shown a severe decline (in the industrial fleet). Both $P$. argus and P. laevicauda were considered "nearly threatened" (Santana et al., 2016), but are considered data deficient in the IUCN red list. Although Panulirus echinatus started to be caught after the decline of these two species (Barreto et al., 2009), it did not show up in the reconstructed database. Indeed, even though Santana et al. (2016) considered that the main threat to P. echinatus is overfishing, this species was considered "data deficient." Again, even for groups of high market value, such as lobsters, detailed landing composition is faulty.

Ucides cordatus has a remarkably high social value, being highly appreciated for human consumption in the northern and northeastern regions, where it is caught by the most socially vulnerable group of fishers (crab gatherers). Even though there are records from Amapá to Santa Catarina, some states have not been monitoring their catches (see, e.g., Espírito Santo). Thus, any assessments of the current status for this resource would not include more recent data, which is particularly worrisome. This crab was not included in IN 445/IBAMA (2014), but it was considered threatened by the São Paulo State Decree N. 60.133 (2014) (Mendonça and Jankowsky, 2017). The status of this species was considered "near threatened," considering both fishing effort and destruction of its estuarine habitat (Pinheiro et al., 2016). The case of C. guanhumi is even more severe, as it was considered "critically endangered" (Pinheiro et al., 2016) and, again, landing reporting is not complete. Additionally, in the state of Bahia, the Official State List of Endangered Fauna Species (Ordinance SEMA N. 37, 2017) includes U. cordatus as "critically endangered" (CR), and C. guanhumi and G. cruentata as vulnerable species (VU), together with 28 commercial species of socioeconomic importance for marine and estuarine fisheries. None of these three species are cited in the IUCN red list. Part of this difficulty in recording crab landings is due to its informal nature. In the Brazilian northeastern region, e.g., crab gathering occurs in small towns or in the outskirts of cities, where there is still some mangrove left. Their landings are hardly ever registered, being part of an informal market that sustains poor fishers (Capistrano and Lopes, 2012).

Another uncommon group is the Stomatopoda, which was reported in the current database for the states of São Paulo and Rio de Janeiro since 1968 and 1992, respectively. Squilla brasiliensis and Hemisquilla braziliensis had already been reported as part of the by-catch of commercial shrimp trawlers in the coast of these two states, being discarded sometimes, but also landed individually (Graça Lopes et al., 2002; Keunecke et al., 2007). No documentation of human consumption of these species was found, even though they have been observed in local restaurants (M Vianna, AO Ávila-da-Silva, and MM Rotundo, personal observation). Silva et al. (2003) had reported the occurrence of stomatopods in pink shrimp industrial fisheries in northern Brazil, where Squilla lijdingi was the most abundant (about $89 \%$ ) among six stomatopod species caught. None of these three species are cited in the IUCN red list.

In addition to these traditional resources caught in Brazilian waters, some new resources have been reported in this updated database, such as sea-urchins (E. lucunter) in São Paulo, in 2011. Even though landings were small (around $4 \mathrm{~kg}$ ), it is expected that it grows due to the high market value and its occurrence throughout the Brazilian coast (Carneiro and Cerqueira, 2018). These authors reported its capture in the state of Bahia where they are known as "pinaúna" and gonads and other meat parts are used for human consumption, but no estimate of annual catch was provided. Within the group of Echinodermata, catches of Holothuria (Halodeima) grisea (sea cucumber) have also been documented in the state of Ceará, where 12.3 tonnes were caught per year in two of its municipalities in 2015-2016, corresponding to 380 thousand specimens (Ponte and Feitosa, 2019), and these catches were included in the reconstructed database. Echinometra lucunter is not included in the IUCN red list, but $H$. grisea is considered of least concern.

\section{CONCLUDING REMARKS AND RECOMMENDATIONS}

Here, some of the resources considered of high importance in Brazilian marine waters were presented and analyzed, organized in a database by state and by species ranging from 1950 to 2015, now available to the public. This database showed that landings are increasing in more recent years, due to increased landings from the industrial fleet. Artisanal landings have been decreasing in the last years due to the decrease observed in the northeastern and southeastern regions. Even though some improvement was shown, the reporting system of landing statistics by common name continue to be an issue, as many species are still lumped together, including those under some degree of threat. Sardinella brasiliensis and demersal fishes were the main resources landed by industrial fishers. Artisanal fishers caught more species than their industrial counterpart, featuring $X$. kroyeri, C. acoupa, and U. cordatus. Fishing resources not previously reported, such as sea urchins and sea cucumbers, were also reported. 
With these new data, it is expected that more thorough analyses will be performed in the future, which, in turn, will support better-informed management decisions. Yet, given that any new analyses performed by the authors of this study granted further corrections in the database, we encourage others using this database in the future to contact one of the authors whenever they find errors or come across information that can fill some of the gaps left behind. These reconstructed databases are important for public policy and may be used in debates about rebuilding populations that have been impacted by overfishing. It is of paramount importance that the Brazilian government resume the collection of landing statistics as this is the most basic information required to manage stocks. Moreover, as previously pointed out by many scientists, landings have to be accompanied by fishing effort to assess the relative impact of fisheries and environmental factors in the current status of the main Brazilian marine stocks. Even though the taxonomic resolution has improved in the last years, there is still room for improvement.

\section{DATA AVAILABILITY STATEMENT}

The datasets presented in this study can be found in online repositories. The names of the repository/repositories and accession number(s) can be found below: Instituto de Pesca, http: //www.propesq.pesca.sp.gov.br/37/conteudo.

\section{AUTHOR CONTRIBUTIONS}

KMFF wrote a first draft of the article, coordinated the reconstruction of the national database, worked on the reconstruction for the state of Sergipe, and revised the reconstruction for all states. EAJ, LMAS, JRETA, and ARRA worked on or updated the reconstruction for Amapá. BB updated the reconstruction for Pará. MBF and ZSA revised the

\section{REFERENCES}

Abdallah, P. R., and Bacha, C. J. C. (1999). Evolução da atividade pesqueira no Brasil: 1960-1994. Teor. Evid. Econ. 7, 9-24.

Arana, P. M., Pezzuto, P. R., Ávila-da-Silva, A. O., Queirolo, D., Perez, J. A. A., and Arfelli, C. A. (2016). Pathways for sustainable industrial fisheries in southeastern and southern Brazil. Lat. Am. J. Aquat. Res. 44, 875-881. doi: 10.3856/vol44-issue5-fulltext-1

Araújo, A. R. R., Barbosa, J. M., Santos, J. P., Carvalho, B. L. F., Garciov Filho, E. B., and Deda, M. S. (2016). Boletim Estatístico da Pesca nos Litorais de Sergipe e Extremo Norte da Bahia - 2014. São Cristóvão: Editora UFS.

Ávila-da-Silva, A. O., and Haimovici, M. (2005). "Peixe-batata (Lopholatilus villarii): diagnótico do estado de explotação nas regiões sudeste-sul do Brasil," in Análise das Principais Pescarias Comerciais da Região Sudeste-sul do Brasil: Dinâmica Populacional das Espécies em Explotação, eds M. C. Cergole, A. O. Ávila-da-Silva, and C. L. D. B. Rossi-Wongtschowski (São Paulo: Instituto Oceanográfico da USP), 74-80.

Ávila-da-Silva, A. O., Bastos, G. C. C., and Tutui, S. L. S. (2001). Atividade pesqueira do Estado de São Paulo: análises das capturas do biênio 1998-1999 com espinhel-de-fundo. Bol. Ins. Pesca 27, 33-38.

Ávila-da-Silva, A. O., Carneiro, M. H., and Fagundes, L. (1999). Sistema gerenciador de banco de dados de controle estatístico de produção pesqueira reconstruction for Maranhão. CAFF revised the reconstruction for Piauí. GS and JAA revised the reconstruction for Ceará. PFML updated the reconstruction for Rio Grande do Norte. GO and CP updated the reconstruction for Bahia. MH-S, JM-F, JC, and GS updated the reconstruction for Espírito Santo. MV and KAK updated the reconstruction for Rio de Janeiro. AOA-S and MHC updated the reconstruction for São Paulo. AOA-S, MHC, and JTM updated the reconstruction for Paraná. IT-S and RS worked on or updated the reconstruction for Santa Catarina, and RFS and GV updated or revised the reconstruction for Rio Grande do Sul. MMR revised the taxonomic list. All authors received a first draft of the article, made their contributions, and approved the submitted version.

\section{FUNDING}

PFML and MH-S thank the National Council for the Scientific and Technological Development $(\mathrm{CNPq})$ for the productivity grants 301515/2019-0 and 312278/2017-9, respectively.

\section{ACKNOWLEDGMENTS}

We would like to thank all local experts throughout Brazil who answered many questions on the correspondence between common and scientific names and on the start of some of the artisanal and industrial fisheries. We would rather not mention here each of them individually than run into the risk of forgetting to name some important collaborators.

\section{SUPPLEMENTARY MATERIAL}

The Supplementary Material for this article can be found online at: https://www.frontiersin.org/articles/10.3389/fmars. 2021.659110/full\#supplementary-material

marítima - ProPesq, Anais do XI CONBEP e do I CONLAEP, 2. Recife, 824-832.

Barreto, A. V., Zani-Teixeira, M. L., Ivo, C. T. C., and Katsuragawa, M. (2009). Biometric relationships of the spotted lobster, Panulirus echinatus, from Tamandaré coastal reefs, Pernambuco State, Brazil. J. Mar. Biol. Assoc. U. K. 89, 1601-1606. doi: 10.1017/s002531540900 0733

Barreto, R. R., Bornatowskib, H., Motta, F. S., Santander-Neto, J., Vianna, G. M. S., and Lessa, R. (2017). Rethinking use and trade of pelagic sharks from Brazil. Mar. Policy 85, 114-122. doi: 10.1016/j.marpol.2017.08.016

Belhabib, D., Hellebrandt Silva, D., Allison, E. H., Zeller, D., and Pauly, D. (2016). Filling a blank on the map: 60 years of fisheries in Equatorial Guinea. Fish. Manag. Ecol. 23, 119-132. doi: 10.1111/fme.12161

Braga, A. S., Vellini, L. L., and Neiva, G. S. (1966). "Notas preliminares sobre a pesca marítima da região Centro Sul do Brasil," in Anais da VII Reunião Nacional de Técnicos em Pesquisas sobre a Pesca Marítima (Santos: São Paulo), 175.

Capistrano, J. F., and Lopes, P. F. M. (2012). Crab gatherers perceive concrete changes in the life history traits of Ucides cordatus (Linnaeus, 1763), but overestimate their past and current catches. Ethnobiol. Conserv. 1:7.

Carneiro, L. S., and Cerqueira, W. R. P. (2018). Informações sobre o ouriço-domar Echinometra lucunter (Linnaeus, 1758) (Echinodermata: Echinoidea) para o litoral de Salvador e adjacências. Sitientibus Sér. Ciênc. Biol. 8, 168-171. 
Carneiro, M. H., Ávila-da-Silva, A. O., and Sakamoto, M. S. (2018). "Diagnóstico pesqueiro," in Métodos de Estudo em Ecossistemas Costeiros: Biodiversidade e Funcionamento, eds A. C. Z. Amaral, A. Turra, ÁM. Ciotti, C. Wongtschowski, and Y. Schaeffer-Novelli (Campinas: UNICAMP), 224-237.

Carneiro, M. H., Namora, R. C., Miranda, L., Mendonça, J., Ávila-da-Silva, A., and Bastos, G. C. (2016). Marine and estuarine fisheries of São Paulo, Brazil: an institutional and methodological framework. Front. Mar. Sci. 3:70.

Castello, J. P. (2010). O futuro da pesca e da aquicultura marinha no Brasil: a pesca costeira. Ciênc. Cult. 62, 32-35.

Cawthorn, D.-M., Baillie, C., and Mariani, S. (2018). Generic names and mislabeling conceal high species diversity in global fisheries markets. Conserv. Lett. 11:e12573. doi: 10.1111/conl.12573

Cergole, M. C., and Dias-Neto, J. (2011). Plano de Gestão Para o Uso Sustentável da Sardinha-Verdadeira Sardinella brasiliensis no Brasil. Série Plano de Gestão dos Recursos Pesqueiros, 5. Brasília: Instituto Brasileiro do Meio Ambiente e dos Recursos Renováveis, 180.

Cisneros-Montemayor, A. M., and Sumaila, U. R. (2010). A global estimate of benefits from ecosystem-based marine recreation: potential impacts and implications for management. J. Bioecon. 12, 245-268. doi: 10.1007/s10818010-9092-7

Costa, P. A. S., Braga, A. C., Rubinich, J. P., Ávila-da-Silva, A. O., and Monteiro Neto, C. (2012). Age and growth of the snowy grouper, Epinephelus niveatus, off the Brazilian coast. J. Mar. Biol. Assoc. U. K. 92, 633-641. doi: 10.1017/ s0025315411000142

Damasio, L. M. A., Lopes, P. F. M., Pennino, M. G., Carvalho, A. R., and Sumaila, U. R. (2016). Size matters: fishing less and yielding more in smaller-scale fisheries. ICES J. Mar. Sci. 73, 1494-1502. doi: 10.1093/icesjms/fsw016

Damásio, L. M. A., Peninno, M. G., and Lopes, P. F. M. (2020). Small changes, big impacts: geographic expansion in small-scale fisheries. Fish. Res. 226:105533. doi: 10.1016/j.fishres.2020.105533

Dias-Neto, J. (2010). Pesca no Brasil e seus aspectos institucionais - um registro para o futuro. Biodiv. Cons. Mar. 1, 66-80. doi: 10.37002/revistacepsul.vol1. 30066-80

Dias-Neto, J., and Dias, J. F. O. (2015). O Uso da Biodiversidade Aquática no Brasil: Uma Avaliação com Foco na Pesca. Brasília: IBAMA.

FAO (2020). The State of World Fisheries and Aquaculture 2020. Sustainability in Action. Rome: Food and Agriculture Organization.

Ferreira, H. M., Reuss-Strenzel, G. M., Alves, J. A., and Schiavetti, A. (2014). Local ecological knowledge of the artisanal fishers on Epinephelus itajara (Lichtenstein, 1822) (Teleostei: Epinephelidae) on Ilhéus coast Bahia State, Brazil. J. Ethnobiol. Ethnomed. 10:51. doi: 10.1186/1746-4269$10-51$

FIPERJ/MPA/UFRJ (undated). Monitoramento da Pesca Industrial no Rio de Janeiro - Capacitação, Pesquisa e Gestão. Rio de Janeiro: FIPERJ/MPA/UFRJ.

Freire, K. M. F. (2003). A database of landing data on Brazilian marine fisheries from 1980 to 2000. Fish. Centre Res. Rep. 11, 181-189.

Freire, K. M. F., and Oliveira, T. L. S. (2007). Reconstructing catches of marine commercial fisheries for Brazil. Fish. Cent. Res. Rep. 15, 61-68.

Freire, K. M. F., and Pauly, D. (2005). Richness of common names of Brazilian marine fishes and its effect on catch statistics. J. Ethnobiol. 25, 279-296. doi: 10.2993/0278-0771(2005)25[279:rocnob]2. $0 . \operatorname{co} ; 2$

Freire, K. M. F., Aragão, J. A. N., Araújo, A. R. R., Ávila-da-Silva, A. O., Bispo, M. C. S., Velasco, G., et al. (2015). Reconstruction of catch statistics for Brazilian marine waters (1950-2010). Fish. Cent. Res. Rep. 23, 3-30.

Freire, K. M. F., Belhabib, D., Espedido, J. C., Hood, L., Kleisner, K. M., Lam, V. W. L., et al. (2020). Estimating global catches of marine recreational fisheries. Front. Mar. Sci. 7:12.

Furtado, L. G., and Nascimento, I. H. (1982). Pescadores de linha no litoral paraense: uma contribuição aos estudos de campesinato na Amazônia. Bol. Mus. Para. Emílio Goeldi 82, 1-49.

Giglio, V. J., Bertoncini, A. A., Ferreira, B. P., Hostim-Silva, M., and Freitas, M. O. (2014). Landings of goliath grouper, Epinephelus itajara, in Brazil: despite prohibited over ten years, fishing continues. Nat. Conserv. 12, 118-123. doi: 10.1016/j.ncon.2014.09.004

Giglio, V. J., Leite, J. R., Freitas, M. O., and Hostim-Silva, M. (2016). Mapping goliath grouper aggregations in the southwestern Atlantic. Braz. J. Oceanogr. 4, 417-420.
Graça Lopes, R., Tomás, A. R. G., Tutui, S. L. S., Rodrigues, E. S., and Puzzi, A. (2002). The shrimp fishery by-catch of the São Paulo State coast, Brazil. Bol. Inst. Pesca 28, 173-188.

Haimovici, M., and Peres, M. B. (2005). "Polyprion americanus (Bloch \& Schneider, 1801)," in Análise das Principais Pescarias Comerciais da Região Sudeste-sul do Brasil: Dinâmica Populacional das Espécies em Explotação, eds M. C. Cergole, A. O. Ávila-da-Silva, and C. L. D. B. Rossi-Wongtschowski (São Paulo: Instituto Oceanográfico da USP), 124-131.

Hostim-Silva, M., and Scheidt, G. S. S. (2013). Boletim estatístico da pesca do Espírito Santo. Ano 2011. Programa de Estatística Pesqueira do Espírito Santo. Vitória: Universidade Federal do Espírito Santo.

Hyndman, R. J., and Khandakar, Y. (2008). Automatic time series forecasting: the forecast package for R. J. Stat. Softw. 26, 1-22.

IBAMA (2007). Estatística da Pesca. 2007. Grandes Regiões e Unidades da Federação. Brasília: Instituto Brasileiro do Meio Ambiente e dos Recursos Naturais Renováveis.

IBGE (2012). Metodologia de Estatísticas de Pesca: Pesca Embarcada. Rio de Janeiro: Instituto Brasileiro de Geografia e Estatística.

Iglésias, S. P., Toulhoat, L., and Sellos, D. Y. (2010). Taxonomic confusion and market mislabelling of threatened skates: important consequences for their conservation status. Aquat. Conserv. 20, 319-333. doi: 10.1002/aqc.1083

Isaac, V. J., Santo, R. V. E., and Nunes, J. L. G. (2008). A estatística pesqueira no litoral do Pará: resultados divergentes. Panamjas 3, 205-213.

Jankowsky, M., Mendonça, J. T., and Morroni, D. (2019). "Monitoramento pesqueiro no litoral do Paraná," in Organizer: Leonardo Tullio Fronteiras Para a Sustentabilidade 2. ed. L. Tullio (Ponta Grossa: Atena Editora), 41-55. doi: 10.22533/at.ed.7311923124

Keunecke, K. A., Vianna, M., Fonseca, D. B., and D’Incao, F. (2007). The pinkshrimp trawling bycatch in the northern coast of São Paulo, Brazil, with emphasis on crustaceans. Nauplius 15, 49-55.

Khalfallah, M., Dimech, M., Ulman, A., Zeller, D., and Pauly, D. (2017). Reconstruction of marine fisheries catches for the Republic of Malta (19502014). Medit. Mar. Sci. 18, 42-51.

Marceniuk, A. P., Molina, E. G., Caires, R. A., Rotundo, M. M., Wosiacki, W. B., and Oliveira, C. (2019). Revision of Bairdiella (Sciaenidae: Perciformes) from the western South Atlantic, with insights into its diversity and biogeography. Neotrop. Ichthyol. 17:e180024.

Marques, R. A., Julio, T. G., Sole-Cava, A. M., and Vianna, M. (2019). A new strategy proposal to monitor ray fins landings in southeast Brazil. Aquat. Conserv. 2019, 1-18.

Mendonça, J. T. (2018). "Monitoramento pesqueiro: avaliação de estratégias de coleta," in A Prática na Investigação Qualitativa: Exemplos de Estudos, eds C. Brandão, J. L. Carvalho, J. Ribeiro, and A. P. Costa (Aveiro, Portugal: Ludomedia), 27-36.

Mendonça, J. T., and Jankowsky, M. (2017). Subsídios Para Avaliação da Extração de Caranguejo-uçá (Ucides cordatus) e Pitu de Iguape (Macrobrachium acanthurus) no Litoral sul de São Paulo. RT-54, Série Relatórios Técnicos. São Paulo: Instituto de Pesca

Menezes, N. A., Nirchio, M., Oliveira, C., and Ramirez, R. S. (2015). Taxonomic review of the species of Mugil (Teleostei: Perciformes: Mugilidae) from the Atlantic South Caribbean and South America, with integration of morphological, cytogenetic and molecular data. Zootaxa 3918, 1-38. doi: 10. 11646/zootaxa.3918.1.1

Moritz, S., and Bartz-Beielstein, T. (2017). imputeTS: time series missing value imputation in R. R Journal 9, 207-218. doi: 10.32614/rj-2017-009

MPA (2012a). Boletim Estatístico da Pesca e Aquicultura. Brasil 2010. Brasília: Ministério da Pesca e Aquicultura.

MPA (2012b). Boletim Estatístico da Pesca e Aquicultura. Brasil 2011. Brasília: Ministério da Pesca e Aquicultura.

MPA (undated). Boletim Estatístico da Pesca e Aquicultura. Brasil 2008-2009. Brasília: Ministério da Pesca e Aquicultura.

Nelson, J. S., Grande, T. C., and Wilson, M. V. H. (2016). Fishes of the World. Hoboken, NJ: John Wiley \& Sons.

Paes, E. T., and Moraes, L. E. (2007). A new hypothesis on the influence of the El Niño/La Niña upon the biological productivity, ecology and fisheries of the Southern Brazilian Bight. Panamjas 2, 94-102.

Pauly, D., and Liang, C. (2019). The fisheries of the South China Sea: major trends since 1950. Mar. Policy 121:103584. doi: 10.1016/j.marpol.2019.103584 
Pauly, D., and Palomares, M. L. D. (2019). Editorial. Historical reconstructions of marine fisheries catches: challenges and opportunities. Front. Mar. Sci. 6:128.

Pauly, D., and Zeller, D. (2016). Global Atlas of Marine Fisheries: a Critical Appraisal of Catches and Ecosystem. Washington: Island Press.

Pereira, A. J. C. Q., Pinheiro, L. M., Leite, N. A. V., and Machado, M. L. (2012). Boletim do Registro Geral da Atividade Pesqueira - RGP. Brasília: Ministério da Pesca e Aquicultura.

Pereira, L. J. G., Fernandes, S. C. P., Gonçalves, F. M., Andrade, C. E. R., and Bentes, B. (2020). Análise multidisciplinar de uma pescaria proibida: estudo de caso da pesca do mero Epinephelus itajara (Lichtenstein, 1822) no litoral paraense, Amazônia oriental. Res. Soc. Dev. 9:e944986338. doi: 10.33448/rsd-v9i8. 6338

Peres, M. B., and Haimovici, M. (1998). A pesca dirigida ao cherne-poveiro Polyprion americanus no sul do Brasil. Atlântica 20, 141-161.

Perez, J. A. A., Pezzuto, P. R., Wahrlich, R., and Soares, A. L. D. S. (2009). Deepwater fisheries in Brazil: history, status and perspectives. Lat. Am. J. Aquat. Res. 37, 513-541. doi: 10.3856/vol37-issue3-fulltext- 18

Pezzuto, P. R., and Borzone, C. A. (2004). The collapse of the scallop Euvola ziczac (Linnaeus, 1758) (Bivalvia: Pectinidae) fishery in Brazil: changes in distribution and relative abundance after 23 years of exploitation. Bras. J. Oceanogr. 52, 225-236. doi: 10.1590/s1679-87592004000300005

Pinheiro, M. A. A., Santos, L. C. M., Souza, C. A., João, M. C. A., Dias-Neto, J., and Ivo, C. T. C. (2016). “Avaliação do caranguejo-uçá, Ucides cordatus (Linnaeus, 1763) (Decapoda: Ucididae). Chapter 33,” in Livro Vermelho dos Crustáceos do Brasil: Avaliação 2010-2014, eds M. A. A. Pinheiro and H. Boos (Porto Alegre: Sociedade Brasileira de Carcinologia), 441-458.

Pio, V. M., Pezzuto, P. R., and Wahrlich, R. (2016). Only two fisheries? characteristics of the industrial bottom gillnet fisheries in southeastern and southern Brazil and their implications for management. Lat. Am. J. Aquat. Res. 44, 882-897. doi: 10.3856/vol44-issue5-fulltext-2

Piroddi, C., Gristina, M., Zylich, K., Greer, K., Ulman, A., Zeller, D., et al. (2015). Reconstruction of Italy's marine fisheries removals and fishing capacity, 1950-2010. Fish. Res. 172, 137-147. doi: 10.1016/j.fishres.2015.06.028

PMAP/Instituto de Pesca de São Paulo (2014). Produção Pesqueira Marinha Desembarcada nos Municípios de Angra dos Reis e Paraty, Estado do Rio de Janeiro, nos anos de 2008-2011. PMAP/Instituto de Pesca de São Paulo.

Ponte, I. A. R., and Feitosa, C. V. (2019). Evaluation of an unreported and unregulated sea cucumber fishery in eastern Brazil. Ocean. Coast. Manag. 167, 1-8. doi: 10.1016/j.ocecoaman.2018.09.016

R Core Team (2020). R: a Language and Environment for Statistical Computing. Vienna: R Foundation for Statistical Computing.

Santana, W., Ivo, C. T. C., Dias-Neto, J., Duarte, L. F. A., Pinheiro, M. A. A., and Boos, H. (2016). “Avaliação das lagostas-de-espinho (Decapoda: Palinuridae). Chapter 21," in Livro Vermelho dos Crustáceos do Brasil: Avaliação 2010-2014, eds M. A. A. Pinheiro and H. Boos (Porto Alegre: Sociedade Brasileira de Carcinologia), 268-283.

Santos, S. R., Pessoa, L. M., and Vianna, M. (2019). Geometric morphometrics as a tool to identify species in multispecific flatfish landings in the Tropical Southwestern Atlantic. Fish. Res. 213, 190-195. doi: 10.1016/j.fishres.2019.01. 017

Silva, K. C. A., Muniz, A. P. M., Viana, G. F. S., Aniceto, I. H., and RamosPorto, M. (2003). Espécies de estomatópodes capturadas na pesca industrial do camarão-rosa e no Programa REVIZEE, na Região norte do Brasil (Crustacea, Stomatopoda). Bol. Téc. Cient. CEPNOR 3, 37-51.

Silva, R., Pedraza-Marrón, C. R., Sampaio, I., Betancur-Gomes, R. G., and Schneider, H. (2020). New insights about species delimitation in red snappers (Lutjanus purpureus and L. campechanus) using multilocus data. Mol. Phylogenet. Evol. 147:106780. doi: 10.1016/j.ympev.2020.106780

Soares, H. C., Pezzi, L. P., Gherardi, D., and Paes, E. T. (2011). Oceanic and atmospheric patterns during spawning periods prior to extreme catches of the Brazilian sardine (Sardinella brasiliensis) in the southwest Atlantic. Sci. Mar. 75, 665-677. doi: 10.3989/scimar.2011.75n 4665

Souza, R. F. C., Pantaleão, G. S. L., Fonseca, A. F., and Ivo, C. T. C. (2008). Sobre a estratificação espacial do pargo, Lutjanus purpureus Poey, 1875, em áreas de pesca da região norte do Brasil. Bol. Téc. Cient. CEPNOR 8, 75-82. doi: 10.17080/1676-5664/btcc.v8n1p 75-82

Stern, N., Douek, J., Goren, M., and Rinkevich, B. (2018). With no gap to mind: a shallow genealogy within the world's most widespread small pelagic fish. Ecography 41, 491-504. doi: 10.1111/ecog.02755

Temple, A. J., Wambijib, N., Poonianc, C. N. S., Jiddawid, N., Steada, S. M., Kiszkae, J. J., et al. (2019). Marine megafauna catch in southwestern Indian ocean small-scale fisheries from landings data. Biol. Conserv. 230, 113-121. doi: 10.1016/j.biocon.2018.12.024

Thomé-Souza, M. J. F., Carvalho, B. L. F., Garciov Filho, E. B., Silva, C. O., Deda, M. S., Félix, D. C. F., et al. (2014a). Estatística Pesqueira da Costa do Estado de Sergipe e Extremo Norte da Bahia 2013. São Cristóvão: Editora UFS.

Thomé-Souza, M. J. F., Carvalho, B. L. F., Silva, C. O., Deda, M. S., Filho, E. B. G., Félix, D. C. F., et al. (2014b). Estatística Pesqueira da Costa do Estado de Sergipe e Extremo Norte da Bahia 2012. São Cristóvão: Editora UFS.

Thomé-Souza, M. J. F., Deda, M. S., Santos, J. P., Carvalho, B. L. F., Araújo, M. L. G., Filho, E. B. G., et al. (2013). Estatística Pesqueira da Costa do Estado de Sergipe e Extremo Norte da Bahia 2011. São Cristóvão: Editora UFS.

Valentini, H., D’Incao, F., Rodrigues, L. F., Rebelo Neto, J. E., and Rahn, E. (1991). Análise da pesca do camarão rosa (Penaeus brasiliensis e Penaeus paulensis) nas regiões sudeste e sul do Brasil. Atlântica 13, 143-157.

Vasconcellos, M., Diegues, A. C., and Kalikoski, D. C. (2011). "Coastal fisheries of Brazil," in Coastal Fisheries of Latin America and the Caribbean, FAO Fisheries and Aquaculture Technical Paper. N. 544, eds S. Salas, R. Chuenpagdee, A. Charles, and J. C. Seijo (Rome: FAO), 73-116.

Vasconcellos, M., Diegues, A. C., and Sales, R. R. (2007). Alguns Aspectos Relevantes Relacionados à pesca Artesanal Costeira Nacional. Brasília: Secretaria Especial de Aquicultura e Pesca.

Viana, J. P. (2013). Recursos pesqueiros do Brasil: situação dos estoques, da gestão, e sugestões para o futuro. Ipea Bol. Reg. Urb. Amb. 7, 45-59.

Vieira, B. B., Carvalho, J. P., Silva, A. G., Braga, A. S., Ramos, F. A., Maia, M. M., et al. (1945). Anuário da Pesca Marítima no Estado de São Paulo: 1944. São Paulo: Departamento da Produção Animal.

Zeller, D., and Pauly, D. (2018). The 'presentist bias' in time-series data: implications for fisheries science and policy. Mar. Policy 90, 14-19. doi: 10. 1016/j.marpol.2018.01.015

Conflict of Interest: The authors declare that the research was conducted in the absence of any commercial or financial relationships that could be construed as a potential conflict of interest.

Publisher's Note: All claims expressed in this article are solely those of the authors and do not necessarily represent those of their affiliated organizations, or those of the publisher, the editors and the reviewers. Any product that may be evaluated in this article, or claim that may be made by its manufacturer, is not guaranteed or endorsed by the publisher.

Copyright (c) 2021 Freire, Almeida, Amador, Aragão, Araújo, Ávila-da-Silva, Bentes, Carneiro, Chiquieri, Fernandes, Figueiredo, Hostim-Silva, Jimenez, Keunecke, Lopes, Mendonça, Musiello-Fernandes, Olavo, Primitivo, Rotundo, Santana, Sant'Ana, Scheidt, Silva, Trindade-Santos, Velasco and Vianna. This is an open-access article distributed under the terms of the Creative Commons Attribution License (CC BY). The use, distribution or reproduction in other forums is permitted, provided the original author(s) and the copyright owner(s) are credited and that the original publication in this journal is cited, in accordance with accepted academic practice. No use, distribution or reproduction is permitted which does not comply with these terms. 